\title{
Role of the Mitochondrial Protein Import Machinery and Protein Processing in Heart Disease
}

\author{
Fujie Zhao and Ming-Hui Zou* \\ Center for Molecular and Translational Medicine, Georgia State University, Atlanta, GA, United States
}

Mitochondria are essential organelles for cellular energy production, metabolic homeostasis, calcium homeostasis, cell proliferation, and apoptosis. About 99\% of mammalian mitochondrial proteins are encoded by the nuclear genome, synthesized as precursors in the cytosol, and imported into mitochondria by mitochondrial protein import machinery. Mitochondrial protein import systems function not only as independent units for protein translocation, but also are deeply integrated into a functional network of mitochondrial bioenergetics, protein quality control, mitochondrial dynamics and morphology, and interaction with other organelles. Mitochondrial protein import deficiency is linked to various diseases, including cardiovascular disease. In this

OPEN ACCESS

Edited by:

Shijun Wang,

Fudan University, China

Reviewed by:

Piotr Bragoszewski,

Nencki Institute of Experimental

Biology (PAS), Poland

Xin Jie Chen,

Upstate Medical University,

United States

*Correspondence:

Ming-Hui Zou

mzou@gsu.edu

Specialty section:

This article was submitted to

Cardiovascular Metabolism,

a section of the journal

Frontiers in Cardiovascular Medicine

Received: 29 July 2021

Accepted: 26 August 2021

Published: 28 September 2021

Citation:

Zhao F and Zou M-H (2021) Role of

the Mitochondrial Protein Import

Machinery and Protein Processing in

Heart Disease.

Front. Cardiovasc. Med. 8:749756

doi: 10.3389/fcvm.2021.749756 review, we describe an emerging class of protein or genetic variations of components of the mitochondrial import machinery involved in heart disease. The major protein import pathways, including the presequence pathway (TIM23 pathway), the carrier pathway (TIM22 pathway), and the mitochondrial intermembrane space import and assembly machinery, related translocases, proteinases, and chaperones, are discussed here. This review highlights the importance of mitochondrial import machinery in heart disease, which deserves considerable attention, and further studies are urgently needed. Ultimately, this knowledge may be critical for the development of therapeutic strategies in heart disease.

Keywords: mitochondrial protein import machinery, heart disease, TOM complex, TIM23 complex, TIM22 complex, CHCHD4 (MIA40)

\section{INTRODUCTION}

Mitochondria are vital for energy production in eukaryotic cells, generating cellular ATP through oxidative phosphorylation (OXPHOS) (1). Importantly, mitochondria are also crucial for numerous metabolic pathways, maintenance of calcium homeostasis, and regulation of cell proliferation and apoptosis (2). However, only 13 proteins involved in OXPHOS are encoded by the mitochondrial genome in mammals. About 99\%-more than 1,500-mammalian mitochondrial proteins are encoded by the nuclear genome, synthesized as precursors in the cytosol, and need to be imported into mitochondria by mitochondrial protein import machinery (3). To date, six translocases of the mitochondrial protein import machinery have been discovered. The TOM complex serves as the entry gate for most precursors at the outer membrane (OM); the TIM22 and TIM23 complexes at the inner membrane (IM) are responsible for the insertion of carrier precursors into the IM and the translocation of presequence-carrying precursors into the mitochondrial matrix or IM individually; the mitochondrial intermembrane space (IMS) import 
and assembly machinery (MIA) complex mediates the import of cysteine-rich proteins to the IMS; the SAM and MIM complexes are responsible for insertion of $\beta$-barrel proteins and $\alpha$-helical proteins, respectively, into the OM (Figure 1 and Table 1) (3). The dynamic interaction and cooperation of these mitochondrial protein import pathways enable cells to respond to environmental stress and energy demands rapidly and with plasticity. Further, mitochondrial protein import pathways function not only as independent units for protein translocation, but also are deeply integrated into a functional network of mitochondrial bioenergetics, protein quality control, mitochondrial dynamics and morphology, and interaction with other organelles (4). Mitochondrial protein import deficiency is linked to various diseases, including neuropathies, myopathies, neurodegenerative diseases, cancer, and cardiovascular disorders $(5,6)$. The heart is a high-energy-requiring organ that depends heavily on mitochondrial activity and the efficient import of mitochondrial proteins. However, in heart disease, the roles of the mitochondrial protein import machinery have not been well-studied. Here, we summarize the current knowledge on mitochondrial protein import in heart disease for the first time. This review highlights the importance of the mitochondrial import machinery in heart disease, which deserves considerable attention, and further studies are urgently needed. Ultimately, this knowledge may be critical for the development of therapeutic strategies in heart disease.

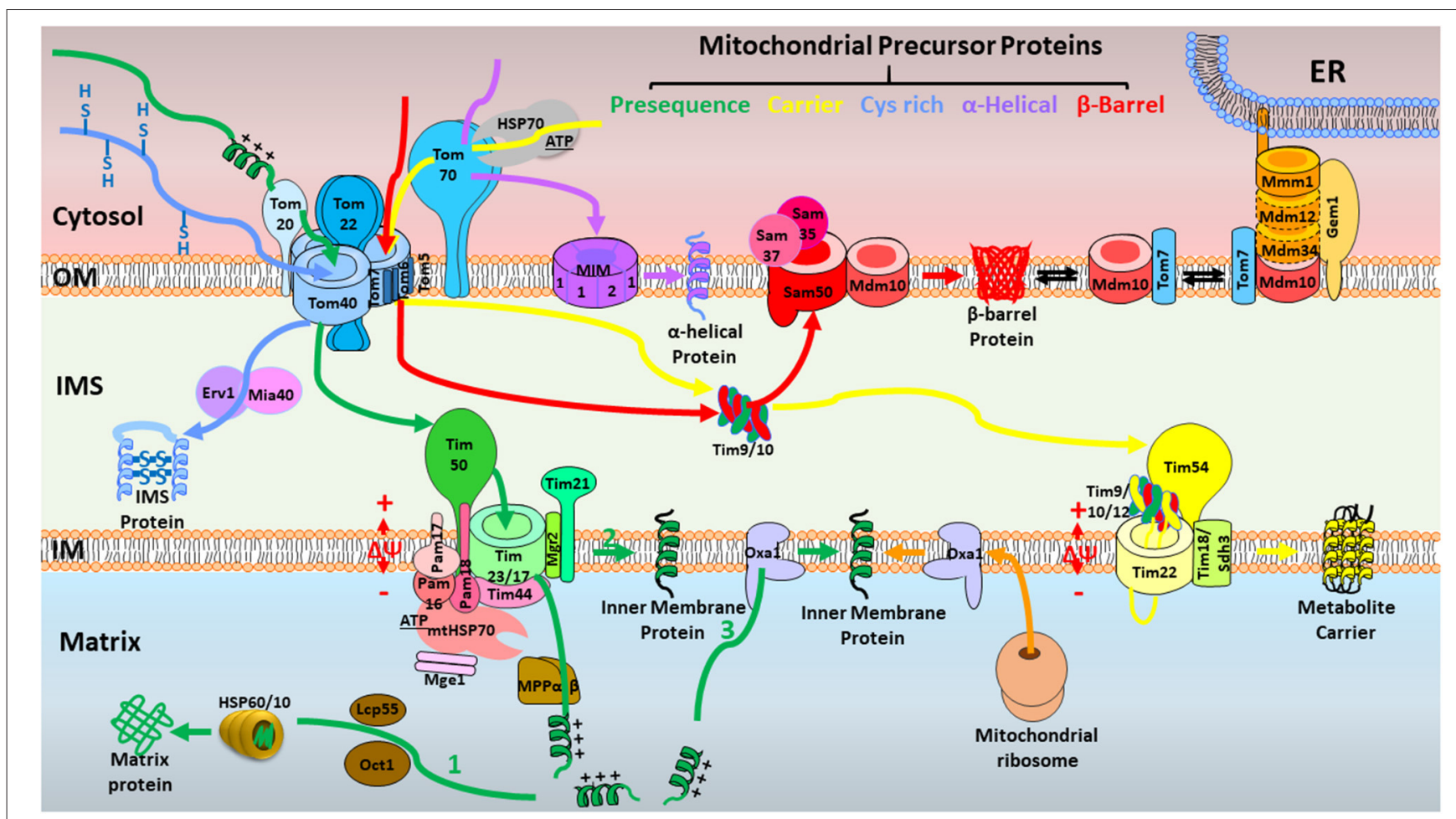

FIGURE 1 | Overview of the major mitochondrial protein import pathways in yeast. First, the presequence pathway transports presequence-carrying cleavable preproteins to the mitochondrial matrix (1) or IM $(2,3)$ (in green). Presequence-carrying precursors to the mitochondrial matrix (1) are typically recognized by TOM at the OM, passage the IM through TIM23, and are driven into the matrix assisted by PAM. $\Delta \psi$ across the IM is essential for the entry of presequences into the matrix. The presequences are cleaved by MPP, and additional proteolytic processing occurs by intermediate cleaving peptidases. Presequence-carrying precursors that integrate into IM follow two distinct routes. IM proteins are either directly laterally released from the TIM23 complex (2) or transported into the matrix first followed by further insertion into the IM with the help of Oxa1 (3). Oxa1 also is responsible for insertion of IM proteins synthesized on mitochondrial ribosomes. Second, in the carrier pathway for the import of precursor proteins without a cleavable presequence, yet with internal targeting signals into the IM (in yellow), carrier precursors are accompanied by cytosolic chaperones, delivered to the Tom70 receptor of the TOM complex, bound by small TIM chaperones in the IMS, and eventually integrated into the IM by the TIM22 complex in a $\Delta \psi$-dependent manner. Third, in the MIA pathway for cysteine-rich proteins to the IMS (in blue), the precursors are kept in a reduced state in the cytosol, imported by the TOM complex, oxidized by the MIA machinery, and stay in an oxidized state in the IMS. Fourth, in the SAM complex for $\beta$-barrel proteins to the OM (in red), the precursors of $\beta$-barrel proteins are imported by the TOM complex at the OM, bound to small TIM chaperones in the IMS, and inserted into the OM by the SAM complex. Fifth, some proteins with $\alpha$-helical transmembrane segments are inserted into the OM by the MIM complex (in purple). Typically, the Tom40 channel is not involved in this route, but Tom70 is indispensable. In addition, ERMES is a complex that connects ER and mitochondrial OM, facilitating the dynamic substrate exchange between ER and mitochondrion. Mdm10 is a protein with dual localization in SAM and ERMES. OM, outer membrane; IM, inner membrane; IMS, intermembrane space; TOM, the translocase of the outer membrane; TIM23, the inner membrane translocase TIM23; PAM, presequence translocase-associated motor; $\Delta \psi$, membrane potential; MPP, mitochondrial processing peptidase; Oxa1, oxidase assembly protein 1; TIM22, the carrier translocase of the inner membrane TIM22; MIA, mitochondrial intermembrane space import and assembly machinery; SAM, sorting and assembly machinery; MIM, mitochondrial import complex; ERMES, endoplasmic reticulum (ER)-mitochondria encounter structure. 
TABLE 1 | Components of mitochondrial import machinery in fungi and mammals.

\begin{tabular}{|c|c|c|}
\hline Complex & $\begin{array}{l}\text { Fungi } \\
\text { (protein/gene name) }\end{array}$ & $\begin{array}{l}\text { Mammals } \\
\text { (protein/gene name) }\end{array}$ \\
\hline \multirow[t]{7}{*}{ TOM } & Tom20/TOM20 & Tom20/TOMM20 \\
\hline & Tom22/TOM22 & Tom22/TOMM22 \\
\hline & Tom70/TOM70 & Tom70/TOMM70 \\
\hline & Tom40/TOM40 & Tom40/TOMM40 \\
\hline & Tom5/TOM5 & Tom5/TOMM5 \\
\hline & Tom6/TOM6 & Tom6/TOMM6 \\
\hline & Tom7/TOM7 & Tom7/TOMM7 \\
\hline \multirow[t]{9}{*}{ TIM22 } & Tim22/TIM22 & Tim22/TIMM22 \\
\hline & Tim9/TIM9 & Tim9/TIMM9 \\
\hline & Tim10/TIM10 & Tim10a/TIMM10A \\
\hline & Tim12/TIM12 & Tim10b/TIMM10B \\
\hline & Tim54/TIM54 & \\
\hline & Tim18/TIM18 & \\
\hline & Sdh3/SDH3 & \\
\hline & & AGK/AGK \\
\hline & & Tim29/TIMM29 \\
\hline \multirow[t]{5}{*}{ TIM23 } & Tim50/TIM50 & Tim50/TIMM50 \\
\hline & Tim23/TIM23 & Tim23/TIMM23 \\
\hline & Tim17/TIM17 & Tim17a/TIMM17A \\
\hline & & Tim17b/TIMM17B \\
\hline & Tim21/TIM21 & Tim21/TIMM21 \\
\hline \multirow[t]{7}{*}{ PAM } & Tim44/TIM44 & Tim44/TIMM44 \\
\hline & mtHsp70/SSC1 & Mortalin/HSPA9 \\
\hline & $\begin{array}{l}\text { (Pam16/Tim16)/ } \\
\text { (PAM16/TIM16) }\end{array}$ & $\begin{array}{l}\text { (Tim16/Magmas)/ } \\
\text { (PAM16/MAGMAS) }\end{array}$ \\
\hline & $\begin{array}{l}\text { (Pam18/Tim14)/ } \\
\text { (PAM18/TIM14) }\end{array}$ & $\begin{array}{l}\text { (DnaJC15/MCJ)/ } \\
\text { DNAJC15 }\end{array}$ \\
\hline & & (DnaJC19/Tim14)/DNAJC19 \\
\hline & (Mge1/GrpE)/GRE1 & mtGrpE/GRPEL1 \\
\hline & Pam17/PAM17 & \\
\hline OXA & Oxa1/OXA1 & Oxa1/OXA1L \\
\hline \multirow[t]{7}{*}{ Matrix } & (Mas1/ק-MPP)/MAS1 & $\beta-\mathrm{MPP} / \mathrm{PMPCB}$ \\
\hline & (Mas2/ $\alpha-M P P) / M A S 2$ & $\alpha-\mathrm{MPP} / \mathrm{PMPCA}$ \\
\hline & MIP/OCT1 & MIP/MIPEP \\
\hline & Hsp60/HSP60 & Hsp60/HSPD1 \\
\hline & Hsp10/HSP10 & Hsp10/HSPE1 \\
\hline & mtHsp70/SSC1 & mtHsp70/GRP75 \\
\hline & (Mge1/GrpE)/GRE1 & mtGrpE/GRPEL1 \\
\hline \multirow[t]{3}{*}{ MIA } & Mia40/MIA40 & Mia40/CHCHD4 \\
\hline & Erv1/ERV1 & ALR/GFER \\
\hline & & AlF/AIFM1 \\
\hline \multirow[t]{5}{*}{ SAM } & Sam50/SAM50 & Sam50/SAMM50 \\
\hline & Sam35/SAM35 & Metaxin-1/MTX1 \\
\hline & Or & Metaxin-2/MTX2 \\
\hline & Sam37/SAM37 & Metaxin-3/MTX3 \\
\hline & Mdm10/MDM10 & \\
\hline \multirow{6}{*}{$\begin{array}{l}\text { Soluble IMS } \\
\text { TIMs }\end{array}$} & Tim9/TIM9 & Tim9/TIMM9 \\
\hline & Tim10/TIM10 & Tim10a/TIMM10A \\
\hline & Tim8/TIM8 & Tim10b/TIMM10B \\
\hline & Tim13/TIM13 & Tim8a/TIMM8A \\
\hline & & Tim8b/TIMM8B \\
\hline & & Tim13/TIMM13 \\
\hline \multirow{4}{*}{$\begin{array}{l}\text { Cytosolic } \\
\text { chaperones }\end{array}$} & Hsp70/(SSB1 or SSB2) & Hsc70/HSPA8 \\
\hline & & Hsp90 alpha/HSP90A \\
\hline & & Tom34/TOMM34 \\
\hline & & AIP/AIP \\
\hline
\end{tabular}

OVERVIEW OF MITOCHONDRIAL PROTEIN IMPORT MACHINERY (IN YEAST) Presequence Pathway to the Mitochondrial Matrix and IM

The presequence pathway is the best characterized pathway, responsible for the import of $\sim 60 \%$ of all mitochondrial proteins (7). The precursor proteins in this pathway carry a cleavable $\mathrm{N}$-terminal presequence that functions as a targeting signal (79). This unique feature of the pathway distinguishes it from all the others, where the precursor proteins do not have cleavable presequences, but possess different kinds of internal targeting signals. Presequence-carrying precursors to the mitochondrial matrix are typically recognized by the translocase of the outer membrane (TOM) (9-11), passaged through the IM by the translocase of the inner membrane (TIM23) (12-16), and driven into the matrix assisted by the presequence translocaseassociated motor (PAM) (Figure 1) (17-24). The membrane potential $(\Delta \psi)$ across the IM is essential for the activation of the TIM23 channel and the translocation of presequences into the matrix (25-28). The presequences are cleaved by the mitochondrial processing peptidase (MPP) $(3,29-31)$, and additional proteolytic processing occurs by intermediate cleaving peptidases $(7,32-34)$. Presequence-carrying precursors that integrate into the IM follow two distinct routes (Figure 1). IM proteins are either directly released laterally from the TIM23 complex (35-37) or transported first into the matrix, followed by further insertion into the IM with the help of the oxidase assembly protein 1 (Oxa1) insertase (38-41). Oxa1 also is responsible for insertion of IM proteins synthesized on mitochondrial ribosomes (42).

The presequences are located at the $\mathrm{N}$-termini of preproteins and typically consist of $\sim 15-50$ amino acids. An essential characteristic of mitochondrial presequences is the formation of an amphipathic $\alpha$-helix that is specifically recognized by mitochondrial import receptors and other mitochondrial import components during preprotein translocation by TOM, TIM23, and PAM (3).

The TOM complex is the main gate for precursors entering mitochondria. The TOM complex is composed of Tom20, Tom22, and Tom70 as receptors, $\beta$-barrel protein Tom 40 forming the channel, and three small associated proteins, Tom5, Tom6, and Tom7 (11, 43-45). Tom20 and Tom22 function cooperatively as the receptors for presequence-carrying precursors $(9,10,46)$. Tom70 mainly functions as the receptor for preproteins with internal targeting sequences, such as carrier precursors (47-52). Presequence-carrying precursors cross the Tom 40 channel as linear polypeptide chains (44, 45, 53-57), and interact with the tail of the Tom22 receptor in the IMS (57). Tom 22 has presequence binding sites on both the cytoplasmic and IMS sides of the OM. The exact roles of the three small subunits, Tom5, Tom6, and Tom7, have not been well-clarified. It has been proposed that they are not essential for TOM functions but are involved in the assembly and stability of the TOM complex (58-61).

The TIM23 complex translocates cleavable preproteins into mitochondrial matrix or IM. Tim50, Tim23, Tim17, and Tim21 
compose the main elements of the TIM23 complex (12, 13, 16, 62-65). Tim50 functions as a presequence receptor that binds preproteins emerging in the IMS (63) and a channel blocker that closes out the TIM23 channel in the absence of preproteins $(25,66-69)$. Tim 23 and associated partner Tim17 form the channel $(16,25,28,64,70,71)$. Tim21, Tim50, and Tim23 expose domains to the IMS that transiently connect the TOM and TIM23 complexes to facilitate the preprotein transfer $(16,67,72-74)$. Additionally, Tim 21 also physically links the TIM23 complex to the respiratory chain III-IV supercomplex [bcl complex and cytochrome $c$ oxidase (COX)] $(65,75,76)$. Tim21 thus plays a dual role in TOM-TIM23 transfer and the recruitment of respiratory chain complexes. A small membrane protein, Mgr2, functions as a lateral gatekeeper for preproteins that are sorted into the $\operatorname{IM}(35,76)$. The $\Delta \psi$ across the $\operatorname{IM}$ is crucial for translocation of the presequences through the Tim 23 channel, which is negative at the matrix side and positive at the IMS side of the IM, whereas presequences are mostly positively charged. Two roles have been assigned to $\Delta \psi$ : activation of TIM23 channel (25) and an electrophoretic effect that drives the import of presequences $(77,78)$.

PAM. The $\Delta \psi$ is a prerequisite for translocation of the presequence across the TIM23 channel. Nevertheless, it is not sufficient to import the entire protein into the matrix. PAM is necessary for the translocation of matrix proteins. The core of PAM is formed by the molecular chaperone mitochondrial $70 \mathrm{kDa}$ heat shock protein $(\mathrm{mtHsp} 70)(17,18)$ and its cochaperones (Tim44, Mge1, Pam16, Pam17, and Pam18) (16, 21, $79,80)$. mtHsp70 binds the unfolded polypeptide chain and drives its translocation into the matrix in an ATP-dependent manner $(17,18)$. The peripheral membrane protein Tim44 is a docking site for mtHsp70 at the TIM23 complex (21). Mge1 (also known as mitochondrial GrpE) stimulates the release of ADP from mtHsp70 (81). Pam16, Pam17, and Pam18 are three membrane-associated co-chaperones. Pam18 (also termed Tim14) is a J-type co-chaperone that stimulates the ATPase activity of mtHsp70 $(82,83)$. The J-related Pam16 (Tim16) forms a complex with Pam18 and functions as a negative regulator (82-86). Pam17 mediates the organization of the TIM23-PAM interaction $(79,87)$.

MPP. Once arriving in the matrix, the presequences of both IM-sorted and matrix-targeted precursors are removed by a heterodimeric enzyme, MPP (3, 29-31, 88). Additional proteases, the intermediate cleaving peptidase (Icp55) (7, 89 ) and the octapeptidyl aminopeptidase (Oct1, also termed mitochondrial intermediate peptidase, $\operatorname{MIP})(90,91)$, can remove destabilizing N-terminal amino acid residues of the imported proteins. mtHSP70 and other chaperones, like the HSP60-HSP10 chaperonin complex, further assist proteins folding into their active forms (92). The clipped presequence peptides undergo subsequent degradation by the matrix peptidasome, termed presequence protease (PreP) or Cym1 $(93,94)$.

OXA translocase is vital for exporting proteins from the mitochondrial matrix into the IM. OXA has three different roles. (1) Proteins encoded by the mitochondrial genome are exported into the IM by Oxal $(42,95-97)$. (2) Some presequence-carrying proteins imported into the matrix via the
TOM-TIM23 machinery are exported into the IM via Oxa1. This import-export pathway is termed conservative sorting of nuclear-encoded IM proteins (38-41, 98-100). (3) Oxa1 is also vital for the assembly of the carrier translocase TIM22 (38, 101).

\section{Carrier Pathway Into the IM}

The carrier pathway is the second mitochondrial protein import pathway to be discovered, and is responsible for importing precursor proteins without a cleavable presequence, yet with different kinds of internal targeting signals (3, 102-104). The carrier precursors are accompanied by cytosolic chaperones, such as the HSP70 and HSP90 classes in the cytosol, directly delivered to the Tom70 receptor of the TOM complex $(47,105,106)$, and then bound by small TIM chaperones in the IMS (107-110) and eventually integrated into the IM by the carrier translocase of the IM (TIM22) complex in a $\Delta \psi$-dependent manner (Figure 1) (109, 111-116).

Chaperone-guided transport of carrier precursors (including chaperones in the cytosol and IMS). The carrier import pathway uses the same mitochondrial entry gate as the presequence pathway, the TOM complex. However, the mechanisms of translocation differ significantly. The involvement of cytosolic $(47,105,106)$ and mitochondrial IMS chaperones, which is crucial to prevent aggregation of the hydrophobic carrier precursors in the aqueous environment, is the main feature distinguishing this from the presequence pathway. Chaperones of the Hsp70 and Hsp90 classes directly participate in delivering the precursors to $\operatorname{Tom} 70(47,105,106)$. The receptor Tom70 possesses two distinct binding sites, one for the precursor and another for a chaperone $(47,49,117)$, ATP is needed to release the precursor proteins from the cytosolic chaperones $(47,48)$. Upon binding to Tom70, the carrier precursors are transferred to the central receptor Tom22, followed by insertion into the Tom40 channel in a loop conformation $(118,119)$, and transferred to small TIM chaperones in the IMS (107-110). These small TIM heterohexameric chaperone complexes, like the Tim9-Tim10 complex $(120,121)$ and the homologous Tim8-Tim13 complex (122), bind to the precursor proteins and transfer them through the aqueous IMS to IM.

Insertion of carrier precursors into the IM. The TIM22 complex consists of the receptor-like protein Tim54, the channelforming protein Tim22, the Tim9-Tim10-Tim12 chaperone complex, and the Tim18-Sdh3 module. The majority of Tim54 domain is exposed to the IMS and probably functions as the binding site for the Tim9-Tim10-Tim12 complex $(123,124)$. The Tim9-Tim10-Tim12 complex is a modified form of the IMS chaperone, docking onto the TIM22 complex $(123,125)$. Carrier precursors are inserted into the Tim22 channel in a $\Delta \psi$ dependent manner (115). The Tim18-Sdh3 module is involved in the assembly of the TIM22 complex $(126,127)$. The carrier precursors are first bound to the Tim9-Tim10-Tim12 chaperone complex on the surface of the translocase. Upon activation of the Tim 22 channel ( $\Delta \psi$-dependent), the precursors are inserted into the translocase, probably in a loop structure. Finally, the proteins are laterally released into the lipid phase of the IM. 


\section{MIA Complex}

Many IMS proteins contain internal targeting signals and characteristic cysteine motifs. In the cytosol, the precursors are kept in a reduced and unfolded state (128). Upon import by the TOM complex (60), they are oxidized by the MIA machinery, and stay in the IMS in an oxidized state (Figure 1). The MIA system consists of two main components: the oxidoreductase Mia40 and the sulfhydryl oxidase Erv1 (129-133).

Mia40 serves as a receptor and protein disulfide carrier. Most IMS proteins are synthesized without cleavable presequences but contain cysteine motifs. Unlike presequencecarrying precursors and carrier precursors, none of the Tom receptors is necessary for the import of MIA substrates $(60,61)$. Instead, upon passage through the Tom40 channel (60), Mia40 functions as a receptor on the IMS side of the Tom 40 channel (133-138). It recognizes an internal signal of the precursor proteins, typically consisting of a hydrophobic element flanked by a cysteine residue $(133,139,140)$. Mia40 binds to precursors via hydrophobic interaction and catalyzes the formation of disulfide bonds in imported proteins $(133,138)$. The disulfide bonds facilitate the conformational stabilization and assembly of many IMS proteins.

Erv1 cooperates with Mia40 in a disulfide relay. Mia40 does not form disulfide bonds de novo. Disulfide bonds are generated by Erv1 and transferred to Mia40 by the formation of transient intermolecular disulfide bonds (141). Mia40 then transfers the disulfides onto the imported protein. Upon transfer of disulfide bonds to proteins, cysteines of Mia40 become reduced and are re-oxidized by Erv1. Electrons originating from the oxidation of imported proteins flow in the opposite direction. They flow from Mia40 to Erv1 and then to $\mathrm{O}_{2}$ or cytochrome $c$ of the respiratory chain (141-144). In addition to most IMS proteins, some IM and matrix proteins are also MIA-system-dependent $(28,71,113,114,145)$.

\section{Sorting Pathways of Mitochondrial OM Proteins}

All the mitochondrial $\mathrm{OM}$ proteins are imported from the cytosol. The membrane contains two different types of integral protein: $\beta$-barrel proteins, which are integrated into the membrane by multiple transmembrane $\beta$-strands, and $\alpha$-helical proteins, which are membrane-anchored by one or more $\alpha$ helical transmembrane segments.

Sorting and Assembly Machinery for $\boldsymbol{\beta}$-Barrel Proteins. The precursors of $\beta$-barrel proteins initially pass through the TOM complex at the OM (146), then bind to small TIM chaperones in the IMS (110), like the carrier precursors, to avoid aggregation (Figure 1). Subsequent insertion of the $\beta$-barrel proteins into the $\mathrm{OM}$ is performed by the SAM complex, which consists of a membrane-integrated protein, Sam50 (Tob55), and two peripheral membrane proteins exposed to the cytosol, Sam35 and Sam37 (147-149). Folding of the $\beta$-barrel proteins occurs at Sam50-Sam35, followed by lateral release into the lipid phase of the OM $(148,150,151)$. Sam 37 directly interacts with Tom22, coupling the TOM and SAM complexes into a transient supercomplex that promotes the efficient transfer of precursor proteins $(54,152)$.

OM Insertion of $\alpha$-Helical Proteins. The main $\alpha$-helical proteins are classified as signal-anchored proteins (containing an $\alpha$-helical transmembrane segment at the $\mathrm{N}$-terminus), tailanchored proteins (containing an $\alpha$-helical transmembrane segment at the C-terminus), and polytopic (multi-spanning) OM proteins. $\alpha$-helical OM proteins are imported via distinct routes that do not involve the Tom40 channel, in contrast to most mitochondrial proteins. The insertion of some signalanchored and polytopic OM proteins is performed by the MIM complex (153-156), which consists of multiple copies of Mim1 and one copy of Mim2, both of which are small single-spanning OM proteins (Figure 1) $(157,158)$. Tom70 is required for the insertion of some polytopic proteins into MIM $(155,156)$. In the case of tail-anchored proteins and some multi-spanning proteins, import is aided by the lipid composition of the membrane, and no proteinaceous machinery has been identified (159-162). However, the exact mechanism for sorting and insertion of $\alpha$ helical outer membrane proteins is only partially understood, and further studies are urgently needed.

\section{INTEGRATION OF MITOCHONDRIAL PROTEIN IMPORT INTO FUNCTIONAL NETWORKS}

Mitochondrial protein import pathways not only function as independent units for protein translocation, but also are deeply integrated into a functional network of mitochondrial bioenergetics, protein quality control, mitochondrial dynamics and morphology, and interaction with other organelles.

The protein import activity serves as a sensor for the fitness and quality of mitochondria. The protein import activity is determined by the energetic state $(\Delta \psi$, ATP levels) and protein homeostasis of mitochondria. Both the translocation of precursor proteins through the TIM23 complex and the TIM22 complex require the $\Delta \psi(25,77,78,113,115,116)$. The ATP-dependent chaperones play essential roles in delivering carrier precursors to Tom70 receptor $(47,48)$, driving presequence precursor translocation to the matrix $(17,18)$ and folding in the matrix (92). Impairment of respiratory chain activity, reduction of ATP levels, and accumulation of misfolded proteins or reactive oxygen species (ROS) in the matrix (163) will directly affect the importdriving activity of the translocases. The protein import activity of mitochondria is thus a sensitive indicator of their energetic state and fitness.

Mitochondrial protein import machinery and respiratory chain assembly. Both the insertion of mitochondrial-encoded proteins from the matrix into the IM and the import of nuclear-encoded precursors from the cytosol into mitochondria rely heavily on the mitochondrial protein import machinery. Increased mitochondrial ROS levels generated by the respiratory chain contribute to decreased mitochondrial translation efficiency (164). In addition, the TIM23 complex forms supercomplexes with respiratory complexes III and IV as 
well as with the ADP/ATP carrier. These interactions of the TIM23 complex facilitate protein import under energy-limiting conditions $(65,75,165)$ and can also promote the assembly of respiratory complexes (166-168). The respiratory chain complexes also function as assembly platforms for some PAM subunits (75).

Mitochondrial protein import machinery associated with protein quality control, specifically in the following aspects: (1) Mitochondrial unfolded protein response (UPR $\left.{ }^{\mathrm{mt}}\right)$ : the stressactivated transcription factor ATFS- 1 contains a mitochondrial presequence and a nuclear localization signal. In healthy mitochondria, ATFS- 1 is imported into the mitochondrial matrix and degraded by the LON AAA+ protease. When mitochondrial import is mildly impaired, ATFS-1 is translocated into the nucleus, where it functions as a transcription factor and induces expression of mitochondrial chaperones, proteases, and other elements to promote recovery of impaired mitochondria (169171). (2) Unfolded protein response activated by mistargeted mitochondrial proteins (UPR [am]): upon mild damage to mitochondrial protein import, some mitochondrial precursors fail to enter mitochondria and accumulate in the cytosol, thus triggering mitochondrial Precursor Over-accumulation Stress (mPOS). This is followed by a stress response termed UPR [am] that reduces cytosolic protein synthesis and increases proteasome activity to clear the mistargeted proteins from the cytosol $(172,173)$. (3) PTEN-induced kinase 1 (PINK1)/Parkin-induced mitophagy: in healthy conditions, PINK1 is imported into the IM by the presequence pathway and processed by MPP and the presenilin-associated rhomboid-like protease PARL, following the retrotranslocation into the cytosol and degradation by the proteasome $(174,175)$. Upon severe damage to mitochondrial protein import, PINK1 remains at the OM bound to the TOM complex, where it phosphorylates ubiquitin and the E3 ubiquitin ligase Parkin, triggering the removal of damaged mitochondria by mitophagy $(176,177)$. (4) Mitochondria as guardian in the cytosol (MAGIC): in certain conditions, some aggregationprone or misfolded cytosolic proteins may be imported into mitochondria for further degradation. This process is termed MAGIC, suggesting a crucial role of mitochondria in cytosolic proteostasis (178). (5) Proteolysis of mitochondrial proteins: upon removal of the presequence by MPP, destabilizing Nterminal amino acid residues of the imported proteins can be further removed by the intermediate cleaving peptidase Icp55 (which removes a single amino acid) or the mitochondrial intermediate peptidase Oct1 (which removes an octapeptide) $(7,34)$. The matrix AAA+ proteases, CLPXP and LON, degrade misfolded proteins and prevent protein aggregation in the matrix (179-182). The IM contains two AAA+ proteases: the i-AAA protease removes misfolded proteins from the IM, IMS, and OM (183-185), whereas the m-AAA protease degrades proteins from the matrix and IM $(186,187)$. Thus, the process of mitochondrial protein import is connected to protein turnover and quality control.

Mitochondrial protein import machinery connected to mitochondrial membrane architecture and dynamics. The mitochondrial contact site and cristae organizing system (MICOS) is a large protein complex enriched at crista junctions of the IM (188-190). It is crucial for the maintenance of inner membrane cristae organization and is embedded into an interactional network with protein translocases, including TOM, SAM, and MIA. Thus, it provides a dynamic link between protein import, mitochondrial membrane dynamics, and membrane contact sites $(136,188,189,191)$.

The inner-membrane fusion protein optic atrophy (OPA1) is an example of how protein import and processing are connected to mitochondrial membrane dynamics. OPA1 is first processed by matrix MPP, generating a long isoform, and further processed by different IM proteases, AAA+ protease, or OMA1 in mammals and Pcp1 in yeast, yielding a short isoform (192-195). The balance between long OPA1 and the short isoform is essential for membrane fusion and fission, which is modulated by stress and mitochondrial energetic state. Thus, the processing of imported mitochondrial protein is linked to mitochondrial fragmentation, mitophagy, or even cell death.

Endoplasmic reticulum-mitochondria encounter structure (ERMES). ERMES is a multi-subunit protein complex that connects the endoplasmic reticulum and mitochondrial OM, mainly formed by the MDM complex $(196,197)$. Other molecules, such as voltage-dependent anion-selective channel (VDAC) (198), TOM70 (199, 200), and inositol trisphosphate (inositol 1,4,5-trisphosphate) receptors (194) also play crucial roles in forming ER-mitochondria contact sites. The outer membrane protein Mdm10 is a subunit of both SAM and MDM complexes (196). The shuttling of Mdm10 between SAM and MDM is regulated by the small protein Tom7 (58, 196, 197, 201). Therefore, TOM, SAM, and ERMES are linked as a functional network, involved in the maintenance of mitochondrial morphology and the transport of lipids and calcium (202-205).

\section{MITOCHONDRIAL PROTEIN IMPORT MACHINERY AND HEART DISEASE}

Mitochondrial dynamics have become a key topic in the field of heart disease. However, only limited studies investigated the involvement of mitochondrial protein import machinery in these diseases (Summarized in Table 2). Moreover, most of these studies were related to the presequence pathway, which undertakes the import of $\sim 60 \%$ of all mitochondrial proteins.

\section{Presequence Pathway Associated With Heart Disease TOM Complex in Heart Disease}

Tom20 is an essential receptor subunit of the TOM complex that recognizes mitochondrial precursor proteins with cleavable $\mathrm{N}$-terminal presequences. Tom 20 expression was reduced by ischemic insults $(206,207)$, and showed a cardioprotective role against ischemia/reperfusion (I/R) injury through enhancing the mitochondrial import of PKCepsilon (PKC $\varepsilon$ ) in an HSP90-dependent manner (208). PKCE, a member of the serine/threonine kinase family, has been demonstrated to play a protective role against cardiac I/R injury (208, 216, 293). Additionally, calcium homeostasis, which is closely related to 
TABLE 2 | Reported proteins or genes in mitochondrial protein import machinery associated with heart disease.

\begin{tabular}{|c|c|c|c|c|}
\hline Protein/gene name & Import pathway/role & $\begin{array}{l}\text { Associated disease/stress or } \\
\text { physiological process }\end{array}$ & Expression or function in disease & References \\
\hline $\begin{array}{l}\text { Tom20/ } \\
\text { TOMM20 }\end{array}$ & $\begin{array}{l}\text { TOM complex/ } \\
\text { Receptor }\end{array}$ & $\begin{array}{l}\text { Myocardial I/R injury; } \\
\text { Cardiac calcium overload }\end{array}$ & $\begin{array}{l}\text { Decreased level of Tom20 protein upon myocardial I/R injury; Potential regulator of cardiac } \\
\text { calcium homeostasis. }\end{array}$ & $(206-210)$ \\
\hline $\begin{array}{l}\text { Tom22/ } \\
\text { TOMM22 }\end{array}$ & $\begin{array}{l}\text { TOM complex/ } \\
\text { Receptor }\end{array}$ & $\begin{array}{l}\text { Cardiac calcium homeostasis; } \\
\text { Cardiac aldosterone synthesis; } \\
\text { Chronic hypoxia }\end{array}$ & $\begin{array}{l}\text { Receptor for mitoBK ca; Promoting the synthesis of cardiac aldosterone; Increased level of } \\
\text { Tom22 mRNA in chronically hypoxic rat hearts. }\end{array}$ & $(211-215)$ \\
\hline $\begin{array}{l}\text { Tom70/ } \\
\text { TOMM70 }\end{array}$ & $\begin{array}{l}\text { TOM complex/ } \\
\text { Receptor }\end{array}$ & $\begin{array}{l}\text { Cardiac hypertrophy; Myocardial I/R } \\
\text { injury; Myocardial infarction; Diabetic } \\
\text { cardiomyopathy; Heart failure }\end{array}$ & $\begin{array}{l}\text { Decreased level of Tom70 protein in hypertrophic and diabetic hearts, upon I/R injury or } \\
\text { post-MI; Altered phosphorylation level of Tom70 in rat hearts with heart failure. }\end{array}$ & $(216-228)$ \\
\hline $\begin{array}{l}\text { Tom } 40 / \\
\text { TOMM40 }\end{array}$ & $\begin{array}{l}\text { TOM complex/ } \\
\text { Channel }\end{array}$ & $\begin{array}{l}\text { Cardiovascular-related traits; Cardiac } \\
\text { arrhythmia; Heat stress-induced } \\
\text { apoptosis; Cardiac aging }\end{array}$ & $\begin{array}{l}\text { TOMM40/APOE locus was associated with the main risk factors for cardiovascular disease; } \\
\text { Homozygous deletion of TOMM40 in mammals was lethal; Heterozygous TOMM } 40 \\
\text { knockdown mice with ECG alteration; Upregulated Tom } 40 \text { associated with heat stress-induced } \\
\text { cardiomyocyte apoptosis; Reduced expression of Tom } 40 \text { in hearts of old DCM patients. }\end{array}$ & $\begin{array}{c}(214,215,229- \\
238)\end{array}$ \\
\hline $\begin{array}{l}\text { Tom5/ } \\
\text { TOMM5 }\end{array}$ & $\begin{array}{l}\text { TOM complex/ } \\
\text { Assisted protein }\end{array}$ & $\begin{array}{l}\text { Lipoprotein-associated } \\
\text { phospholipase A2 activity }\end{array}$ & Correlated with increased activity of lipoprotein-associated phospholipase A2. & (239) \\
\hline $\begin{array}{l}\text { Tim50/ } \\
\text { TIMM50 }\end{array}$ & $\begin{array}{l}\text { TIM23 complex/ } \\
\text { Receptor }\end{array}$ & $\begin{array}{l}\text { Cardiovascular developmental } \\
\text { defects; DCM and cardiac } \\
\text { hypertrophy }\end{array}$ & $\begin{array}{l}\text { Loss of Tim50 impaired cardiac development in zebrafish embryos; Tim50 deficiency } \\
\text { exacerbated cardiac hypertrophy in mice; Downregulated expression of Tim50 in human DCM } \\
\text { hearts and in murine hypertrophic hearts. }\end{array}$ & $(240,241)$ \\
\hline $\begin{array}{l}\text { Tim23/ } \\
\text { TIMM23 }\end{array}$ & $\begin{array}{l}\text { TIM23 complex/ } \\
\text { Channel }\end{array}$ & $\begin{array}{l}\text { Myocardial H/R or I/R injury; } \\
\text { DCM }\end{array}$ & Reduced Tim23 expression level in hearts of patients with DCM, upon H/R or I/R injury. & $\begin{array}{c}(207,238,242- \\
244)\end{array}$ \\
\hline $\begin{array}{l}\text { mtHSP70/ } \\
\text { GRP75 }\end{array}$ & $\begin{array}{l}\text { TOM-TIM23 pathway/ } \\
\text { PAM }\end{array}$ & $\begin{array}{l}\text { Myocardial H/R injury; } \\
\text { Diabetic cardiomyopathy; Chronic AF }\end{array}$ & $\begin{array}{l}\text { Decreased expression of mtHSP70 upon H/R injury, in IFM of T1DM hearts and SSM of T2DM } \\
\text { hearts; Increased expression of mtHSP7O in human hearts with chronic AF. }\end{array}$ & $(245-249)$ \\
\hline $\begin{array}{l}\text { Tim14/ } \\
\text { DNAJC19 }\end{array}$ & $\begin{array}{l}\text { TOM-TIM23 pathway/ } \\
\text { IM cochaperone }\end{array}$ & DCMA syndrome & $\begin{array}{l}\text { Mutations in DNAJC19 were related to DCMA syndrome, a novel autosomal recessive } \\
\text { syndrome characterized by early-onset DCM, non-progressive cerebellar ataxia, testicular } \\
\text { dysgenesis, growth failure, mild developmental delay, and 3-methylglutaconic aciduria. }\end{array}$ & $(250-255)$ \\
\hline $\begin{array}{l}\text { MAGMAS/ } \\
\text { MAGMAS }\end{array}$ & $\begin{array}{l}\text { TOM-TIM23 pathway/ } \\
\text { IM cochaperone }\end{array}$ & Early death due to heart failure & Two patients from a family with MAGMAS mutation died at 2 years of age of heart failure. & (256) \\
\hline $\begin{array}{l}\text { HSP90/ } \\
\text { HSP90A }\end{array}$ & $\begin{array}{l}\text { TOM-TIM23 pathway/ } \\
\text { Cytosolic chaperone }\end{array}$ & Myocardial I/R injury & HSP90 played a beneficial role against myocardial I/R injury. & $\begin{array}{l}(208,217,257- \\
262)\end{array}$ \\
\hline $\begin{array}{l}\text { HSP60/HSPD1 and } \\
\text { HSP10/HSPE1 }\end{array}$ & $\begin{array}{l}\text { TOM-TIM23 pathway/ } \\
\text { MM chaperones }\end{array}$ & $\begin{array}{l}\text { DCM; Myocardial I/R injury; chronic } \\
\text { AF; Early death due to heart failure }\end{array}$ & $\begin{array}{l}\text { Cardiac-specific HSP60 deficiency in mice led to DCM; HSP10 overexpression protected } \\
\text { against myocardial I/R injury; Both HSP60 and HSP10 were upregulated in human hearts with } \\
\text { chronic AF; A girl with HSP60 deficiency died at } 2 \text { days of age of heart failure. }\end{array}$ & $(263-266)$ \\
\hline $\begin{array}{l}\text { MPP } \alpha / \\
\text { PMPCA }\end{array}$ & $\begin{array}{l}\text { TOM-TIM23 pathway/ } \\
\text { MPP }\end{array}$ & $\begin{array}{l}\text { PMPCA gene mutation-associated } \\
\text { multisystem impairments; Myocardial } \\
\text { I/R injury }\end{array}$ & $\begin{array}{l}\text { PMPCA mutants had multisystem impairments, including developmental delay, severe } \\
\text { hypotonia, ataxia, lactic acidemia, severe hypertrophic left ventricular cardiomyopathy; } \\
\text { Downregulation of MPP } \alpha \text { was beneficial to cardiomyocytes during I/R injury. }\end{array}$ & $(258,267)$ \\
\hline $\begin{array}{l}\text { MIP/ } \\
\text { MIPEP }\end{array}$ & $\begin{array}{l}\text { TOM-TIM23 pathway/ } \\
\text { MPP }\end{array}$ & $\begin{array}{l}\text { COXPD31/Eldomery-Sutton } \\
\text { syndrome }\end{array}$ & $\begin{array}{l}\text { Mutations in the MIPEP gene caused COXPD31/Eldomery-Sutton syndrome, a recessive } \\
\text { disorder with developmental delay, cardiomyopathy, cataracts, hypotonia, left ventricular } \\
\text { non-compaction, variable seizures. }\end{array}$ & (268) \\
\hline $\begin{array}{l}\text { Lon Protease/ } \\
\text { LONP1 }\end{array}$ & $\begin{array}{l}\text { TOM-TIM23 pathway/ } \\
\text { MM Protease }\end{array}$ & $\begin{array}{l}\text { High-fat diet stress; Cardiac } \\
\text { hypertrophy; Hypoxia insults; Cardiac } \\
\text { aging; Friedreich's ataxia }\end{array}$ & $\begin{array}{l}\text { Lon seemed beneficial to cardiomyocytes upon high-fat diet and hypertrophic stresses but } \\
\text { harmful to cardiomyocytes upon hypoxia insults; In aged hearts, Lon expression increased, but } \\
\text { proteolytic efficiency declined; In cardiac-specific frataxin-deletion mice, Lon expression and } \\
\text { activity were increased in the heart. }\end{array}$ & $(269-276)$ \\
\hline $\begin{array}{l}\text { YME1L/ } \\
\text { YME1L1 }\end{array}$ & $\begin{array}{l}\text { TOM-TIM23 pathway/ } \\
\text { MM Protease }\end{array}$ & $\begin{array}{l}\text { DCM and heart failure; Experimental } \\
\text { autoimmune myocarditis; Myocardial } \\
\text { infarction }\end{array}$ & $\begin{array}{l}\text { Cardiac-specific ablation of YME1L in mice led to DCM and heart failure; YME1L was also } \\
\text { crucial for the progression of experimental autoimmune myocarditis to DCM and the } \\
\text { therapeutic efficacy of mesenchymal stem cells in myocardial infarction. }\end{array}$ & $(195,277-279)$ \\
\hline
\end{tabular}




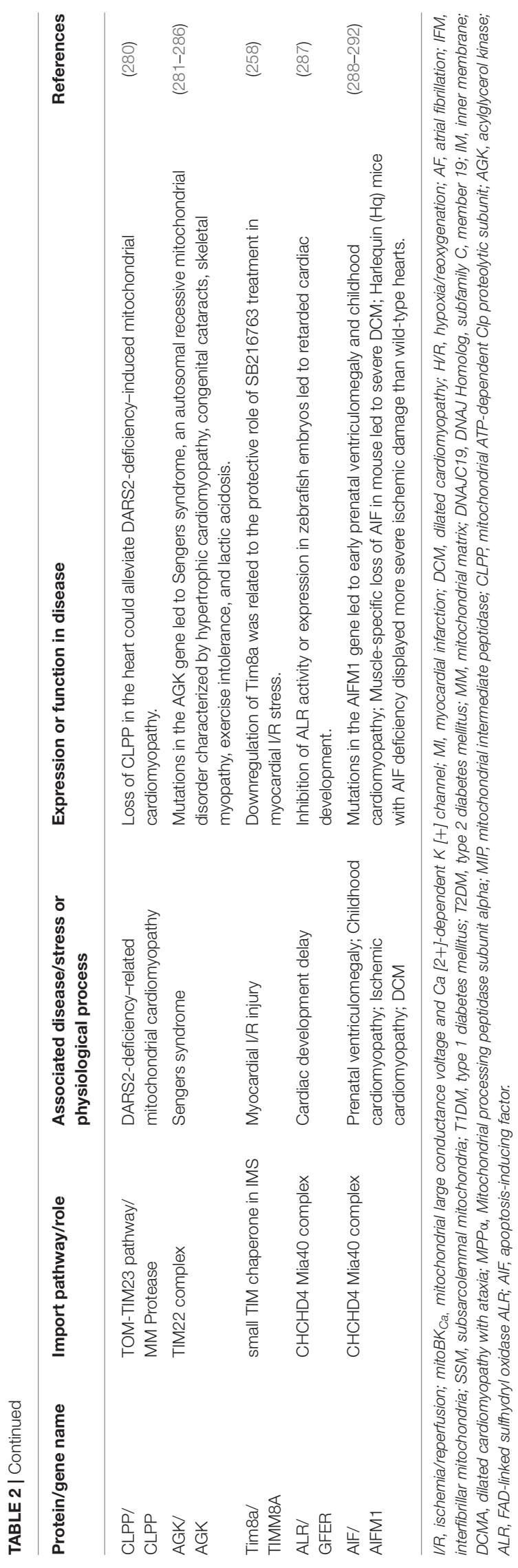

cardiac health, is influenced by Tom 20. For example, Wattamon recently reported that the protective role of fibroblast growth factor 2 (FGF-2) against calcium overload was partially mediated by mitochondrial connexin 43 (Cx43) (introduced below), probably in a Tom20-dependent manner (209). Cx43 was imported into mitochondria via a Tom20-dependent pathway (257). In another study, Tom 20 was reported to be responsible for the direct insertion of VDAC, a protein crucial in regulating cardiac calcium homeostasis (210) through mitochondrial permeability transition pore (mPTP) (294) and mitochondriaassociated endoplasmic reticulum membranes (MAMs), into the $\mathrm{OM}$ of heart mitochondria in rats (295). Thus, Tom 20 could be a crucial adaptor of cardiac calcium homeostasis in a $\mathrm{Cx} 43$ - or VDAC-associated manner.

Tom22 serves as the central receptor for both presequence precursors and carrier precursors. Furthermore, it is also the key factor linking the TOM and SAM complex to a supercomplex by interaction with Sam37, which promotes the efficient transfer of $\beta$-barrel precursors. Tom 22 was recently identified as a potential receptor for cardiac mitochondrial large conductance voltage and $\mathrm{Ca}^{2+}$-dependent $\mathrm{K}[+]\left(\right.$ mitoBK $\left._{\mathrm{Ca}}\right)$ channels, facilitating the import of mitoBK $\mathrm{Ca}$ via the presequence pathway (211). Tom 22 deficiency might induce cardiomyocyte dysfunction by interfering with cardiac mitochondrial $\mathrm{Ca}^{2+}$ import (211). Additionally, Tom 22 has been reported as a potential regulator of heart function through assisting the synthesis of cardiac aldosterone in mitochondria (212). Finally, in chronically hypoxic rat hearts, the level of Tom 22 mRNA was increased in cardiac ventricles (213), suggesting a potential role of Tom22 in ischemic heart disease.

Tom40, encoded by the TOMM40 gene, forms the main protein-conducting channel of the TOM complex. Previous studies indicated TOMM40 was genetically associated with cardiovascular-related traits $(214,215,229,230)$. Several genome-wide association studies (GWAS) have identified that the TOMM40/APOE locus was strongly associated with lowdensity lipoprotein cholesterol [rs157580 (231)], high-density lipoprotein cholesterol [rs2075650, (232), rs157581 (233)], highsensitivity C-reactive protein [rs2075650 (234)], type 2 diabetes [rs157580 (231)], or metabolic syndrome (235). Additionally, experimental evidence showed that homozygous deletion of TOMM40 in mammals was lethal, and heterozygous TOMM40 knockdown mice were found to have cardiac arrhythmia that deteriorated with age (236). Upregulated Tom40 transcription was reported associated with heat stress-induced apoptosis of rat cardiomyocytes (237). Moreover, expression of Tom40 and Tim23 was reduced only in older dilated cardiomyopathy (DCM) patients but not in younger DCM patients, suggesting age-related alterations of these proteins (238).

Small Tom Proteins (Tom5, Tom6, and Tom7). An allele of TOMM5 (the gene encoding Tom5) intronic variant (rs57578064) was correlated with a significant increase in lipoprotein-associated phospholipase A2 activity, which is associated with increased risk of cardiovascular events (239). Tom7 deficit in endothelial cells particularly damaged formation of the cerebrovascular network, but not cardiac vasculature, in zebrafish and mice (296). 


\section{TIM23 Complex in Heart Disease}

Tim23, the channel-forming protein of the TIM23 complex, responsible for the translocation of presequence precursors into mitochondrial matrix or IM, was reduced by hypoxia/reoxygenation (H/R) or I/R (207, 242, 243). Restoring expression of $\operatorname{Tim} 23$ by various treatments seemed protective $(207,242,243)$ against H/R or I/R injuries. However, a controversial study from Bian showed that the protective role of zinc against $\mathrm{I} / \mathrm{R}$ injury was mediated by enhanced mitophagy, accompanied by downregulation of Tom 20 and Tim23 expression (244). In addition, another study reported the association of decreased $\operatorname{Tim} 23$ expression in patients with DCM (238).

Tim50 is the receptor of the TIM23 complex that recognizes presequence carrying proteins. Guo et al. demonstrated that the loss of Tim50 during early zebrafish embryonic development caused neurodegeneration, cardiovascular defects (dysmorphic heart, reduced heartbeat, and decreased circulating blood), and impaired motility. These pathological changes might result from increased cell death, which was mediated by mitochondrial membrane permeabilization and acceleration of cytochrome $c$ release (240). Tang et al. further identified that Tim50 was downregulated in both human DCM heart and transverse aortic constriction (TAC)-induced murine hypertrophic heart (241). Meanwhile, global Tim50 knockout mice showed more severe cardiac hypertrophy than wild-type mice, which was alleviated by cardiac-specific overexpression of Tim50 via reducing ROS accumulation and ASK1 activity (241).

\section{The Presequence-Pathway-Associated Chaperones in Heart Disease}

mtHSP70 (also known as GRP75/ mortalin/ PBP74) is an essential ATP-dependent chaperone of the PAM complex. It drives the translocation of preproteins into the matrix in the membrane-bound motor form and exhibits typical chaperone activity to prevent protein misfolding and aggregation in the soluble form. In vitro studies, mtHSP70 was identified as a cardioprotective chaperone against H/R-induced oxidative stress $(245,246)$, potentially via increased import of nuclear genome-encoded antioxidant defense proteins, such as DJ1 (246). Expression of mtHSP70 was significantly decreased in the interfibrillar mitochondria (IFM) of type 1 diabetes mellitus (T1DM) (247) and the subsarcolemmal mitochondria (SSM) of type 2 diabetes mellitus (T2DM) (248). Cardiacspecific mtHSP70 overexpression restored cardiac function and nuclear-encoded mitochondrial protein import, contributing to a beneficial impact on proteome signature and enhanced mitochondrial function during T2DM (248). Further, mtHSP70 expression was increased in myocardial samples from patients with chronic atrial fibrillation, which suggested an adaptive heat shock response to restore cellular homeostasis (249).

HSP60 and HSP10 are mitochondrial matrix chaperones, playing pivotal roles in implementing protein folding and preventing protein aggregation. Cardiac-specific HSP60 deficiency in mice led to DCM, heart failure, and lethality. Interestingly, the import of preproteins into mitochondria was unaffected by HSP60 deficiency. However, the imported proteins processed by HSP60 underwent further degradation, suggesting lower stability of those proteins (263). HSP10 showed a similar cardioprotective role in I/R-induced myocyte death (264). Both the beneficial roles of HSP60 and HSP10 in cardiomyocytes were related to the preserved function of Complex I and Complex II. Clinical evidence found upregulated expression of both mitochondrial HSP60 and HSP10 in myocardial samples from patients with chronic atrial fibrillation (265). Agsteribbe et al. reported a single case of a girl who had facial dysmorphic features and breathing difficulties upon birth and died at 2 days of age of heart failure (266). The post-mortem examination revealed that the amount of mitochondrial HSP60 was only about 1/5 of the normal level (266).

Tim14 (encoded by DNAJC19), human homolog to yeast Pam18/Tim14, is a mitochondrial IM co-chaperone of the TIM23 complex. Mutations in DNAJC19 were related to DCM and cerebellar ataxia (DCMA) syndrome, a novel autosomal recessive syndrome characterized by early-onset DCM with conduction defects, non-progressive cerebellar ataxia, testicular dysgenesis, growth failure, mild developmental delay, and 3methylglutaconic aciduria, with or without sensorineural hearing loss and basal ganglia lesions (250-255). The pathogenic mechanism of DCMA was associated with protein import inefficiency and cardiolipin remodeling. Experimental evidence suggested DNAJC19 forms a complex with prohibitins (PHBs). Furthermore, the loss of PHB/DNAJC19 complexes affected cardiolipin acylation and led to the accumulation of cardiolipin species with altered acyl chains (297).

MAGMAS (mitochondria-associated granulocyte macrophage colony stimulating factor signaling molecule), also termed PAM16/Tim16, forms a stable subcomplex with J-protein Pam18 or DnaJC19. It tethers to the TIM23 complex in yeast and humans (298). Cybel et al. reported that two patients from a family with MAGMAS mutation died at 2 years of age of heart failure (256).

HSP90, a chaperone mainly located in the cytoplasm, also played a beneficial role against I/R injury $(258,259)$ through translocation of PKCe, $(208,217)$ Cx43, (257, 260) AKT, (261), and Pim1/Lon (262) into mitochondria, potentially via the HSPTOM mitochondrial import pathway.

\section{The Presequence-Pathway-Associated Proteinases and Peptidases in Heart Disease}

Mitochondrial Lon Protease is crucial for the clearance of oxidized or misfolded proteins in the matrix. It played a beneficial role in improving cardiac metabolic flexibility via degradation of pyruvate dehydrogenase kinase 4 in mice fed a high-fat diet (269). Moreover, it was also verified to enhance cardiac function via improving mitochondrial respiration capacity in pressure overload-induced heart failure in mice (270). However, it seemed harmful to cardiomyocytes upon hypoxia insults, which was associated with enhanced ROS production $(271,272)$ and accelerated degradation of phosphorylated complex IV subunits (273). In murine heart, mitochondrial Lon protease levels rose with age, but proteolytic efficiency and adaptation to stress were compromised in older animals $(274,275)$. Mitochondrial Lon protease was also found to be involved in Friedreich's 
ataxia (FRDA), a rare hereditary neurodegenerative disease characterized by progressive ataxia and cardiomyopathy due to mitochondrial frataxin defect. In cardiac-specific frataxindeletion mice, a progressive increase in mitochondrial Lon and $\mathrm{ClpP}$ protease expression and activity were found in the heart, accompanied by the loss of mitochondrial $\mathrm{Fe}-\mathrm{S}$ proteins (276).

YME1L. As we mentioned above, the balance between long OPA1 (L-OPA1) and short OPA1 (S-OPA1), which is crucial for mitochondrial fusion and fission, is modulated by two mitochondrial proteases, OMA1 and the AAA+ protease YME1L. Cardiac-specific ablation of YME1L in mice led to DCM and heart failure via activated OMA1 and accelerated OPA1 proteolysis, which triggered mitochondrial fragmentation and altered cardiac metabolism (195). Moreover, cardiac function and mitochondrial morphology were rescued by Omal deletion by preventing OPA1 cleavage (195). The regulation of YME1L in mitochondrial fusion via OPA1 proteolysis was further verified in experimental autoimmune myocarditis animals (277) and YME1L-overexpressing or deficit cells (278). Furthermore, it was related to the therapeutic efficacy of mesenchymal stem cells for myocardial infarction (279).

$\mathbf{M P P} \alpha . \mathrm{MPP}$ is a dimeric protease in the matrix that removes N-terminal presequences and consists of $\mathrm{MPP} \alpha$ and MPP $\beta$. Mugdha reported that a patient with mutations in the PMPCA gene, which encodes $\mathrm{MPP} \alpha$, had multisystem impairments, including developmental delay, severe hypotonia, ataxia, lactic acidemia, and severe hypertrophic left ventricular cardiomyopathy and died at 14 months from respiratory failure (267). This phenotype may be related to reduced MPP $\alpha$ levels and impaired processing of frataxin and other mitochondrial proteins. Downregulation of $\mathrm{MPP} \alpha$ was found linked to the protective role of GSK inhibitor SB216763 in I/R injury (258).

MIP/Oct1. Upon removal of the presequence by MPP, some mitochondrial precursor proteins undergo secondary processing carried out by the mitochondrial intermediate peptidase MIP/Oct1 or intermediate cleaving peptidase Icp55/XPNPEP3 to remove destabilizing $\mathrm{N}$-terminal amino acid residues of the imported proteins. Mutations in the MIPEP gene, which encodes MIP, causes COXPD31/Eldomery-Sutton syndrome with developmental delay, cardiomyopathy, left ventricular noncompaction, hypotonia, and infantile death (268).

CLPP (mitochondrial ATP-dependent Clp proteolytic subunit), a mitochondrial matrix proteinase, has a central role in protein homeostasis. Loss of CLPP in the heart was found to alleviate mitochondrial cardiomyopathy induced by DARS2 deficiency, potentially mediated by increased de novo synthesis of individual OXPHOS subunits, without affecting the mammalian UPR [mt] (280).

\section{Carrier Pathway Involved in Heart Disease}

Tom70 mainly serves as the receptor for hydrophobic precursors without a cleavable presequence, such as carrier precursors. Tom70 protein was downregulated in hypertrophic heart of animals and humans, which was associated with increased oxidative stress. Furthermore, upregulation of Tom70 provided cardiomyocytes with full resistance to diverse pro-hypertrophic insults (218). Tom70 expression was also reduced by I/R insult in cardiomyocytes (219-222). Supplementation of Tom70 significantly attenuated I/R injury by promoting translocation of PKCE $(216,217)$ [to increase the expression of KATP channel pore-forming subunit Kir6.2 (223), augment mitochondrial respiratory capacity, and modulate cardiac glucose metabolism (224)], MICU1 (to reduce mitochondrial $\mathrm{Ca}^{2+}$ overload), (222) and PINK1 (associated with mitophagy) $(221,225)$ into mitochondria. Increased expression of PGC-1 $\alpha /$ Tom70 was also involved in melatonin-induced cardiac protection against post-myocardial infarction, which was associated with inhibited mitochondrial impairment and reduced ROS generation $(219,220)$. In the hearts of diabetic $\mathrm{db} / \mathrm{db}$ mice, Tom70 expression was suppressed. Reconstitution of Tom70 protected against diabetic cardiomyopathy through its antioxidant and antiapoptotic properties (226). Moreover, in aging hearts of diabetic $\mathrm{db} / \mathrm{db}$ mice, only the expression of mitochondrial membrane proteins like Tom70 and VDAC, but not respiratory enzymes, could be increased by short-term exercise (227). Further, phosphoproteome mapping in a rat model of heart failure revealed phosphorylation of several import machinery proteins (Tom70, HSP90, and Tim8a), suggesting that the modification of mitochondrial protein import was involved in heart failure (228).

AGK (acylglycerol kinase). AGK is a mitochondrial lipid kinase that was recently identified as a subunit of the TIM22 complex. It plays an indispensable role in the import and assembly of mitochondrial carrier proteins in the IM (299). It has been shown that loss-of-function mutations in the AGK gene cause Sengers syndrome (281-286), an autosomal recessive mitochondrial disorder characterized by hypertrophic cardiomyopathy, congenital cataracts, skeletal myopathy, exercise intolerance, and lactic acidosis. Loss of AGK led to destabilized TIM22 complex; defects in the biogenesis of carrier substrates (such as adenine nucleotide translocator); lower complex I, III, and IV activities; perturbed tricarboxylic acid (TCA) cycle; and higher citrate synthase activity (300).

Tim8a (Tim8a/DDP1 and Tim8b/DDP2 are human homologs of yeast Tim8) is a small TIM chaperone in the IMS. Tim8a expression in ischemic rat heart was downregulated by treatment with GSK inhibitor SB216763, which showed a protective effect against I/R stress (258), suggesting a potential role of Tim8a in ischemic heart disease.

\section{MIA Machinery Related to Heart Disease}

FAD-linked sulfhydryl oxidase ALR is the human homolog of yeast Erv1. The interaction between Mia40 and Erv1/ALR facilitates the import of the small Tim proteins and cysteinerich proteins. Inhibition of ALR activity by MitoBloCK- 6 or a translation initiation codon (ATG) morpholino targeted to ALR in zebrafish embryos led to retarded cardiac development and impaired cardiac function (287).

Apoptosis-Inducing Factor (AIF) was initially characterized as a pro-apoptotic factor. It translocates from the mitochondrial IMS to the nucleus in the presence of apoptotic insults. It is also critical for the mitochondrial import and maturation of CHCHD4 (in human)/Mia40 (in yeast) (301-303). Mutations of the AIF-encoding gene AIFM1 led to early prenatal 
ventriculomegaly (288) and childhood cardiomyopathy (289), accompanied by respiratory chain complex I and IV deficiency. Global loss of AIF in mice during embryogenesis resulted in embryonic growth retardation and death during mid-gestation. Muscle-specific loss of AIF in mice led to severe DCM and skeletal muscle atrophy, associated with a significant defect in respiratory chain complex I activity (290). The Harlequin (Hq) mice, a genetic model with an $80 \%$ reduction in mitochondrial AIF, displayed more severe ischemic damage than wild-type hearts after acute I/R injury $(291,292)$.

\section{Other Molecules Involved in Heart Disease by Impacting Mitochondrial Protein Import Efficiency or Altering Mitochondrial Protein Translocation}

Cardiolipin (CL) is a unique phospholipid that is localized and synthesized in mitochondrial IM. CL plays a central role in many biological processes, such as mitochondrial biogenesis, protein import, morphology and mitophagy, oxidative phosphorylation, and apoptosis (304-306). Defective remodeling of CL due to genetic mutations of TAZ-1 causes Barth syndrome, a rare, X-linked recessive, infantile-onset debilitating disorder characterized by early-onset cardiomyopathy, skeletal myopathy, growth delay, and neutropenia (304-309). The molecular mechanisms were partially mediated by impaired mitochondrial import machinery. CL was verified to play a central role in the structural integrity and functions of mitochondrial translocases, such as TOM Complex $(44,310)$, TIM22 Complex, and TIM23 Complex $(26,311,312)$.

Connexin $43(\mathrm{Cx} 43)$ is the predominant protein forming gap junctions and non-junctional hemichannels in ventricular cardiomyocytes and is also localized at the IM of cardiomyocyte mitochondria (313-315). The translocation of Cx43 to the IM was TOM-HSP90-dependent and was enhanced by ischemic preconditioning (IP). The beneficial role of mitochondrial $\mathrm{Cx} 43$ in $\mathrm{I} / \mathrm{R}$ stress was associated with its regulation of mitochondrial potassium influx and ROS production $(257,313-315)$. The cardioprotection of IP was abolished by genetic ablation of Cx43, blockade of mitochondrial Cx43 import, or age-related loss of mitochondrial Cx43 (257, 316-318).

PINK1 is imported into the mitochondrial matrix in healthy conditions, followed by retrotranslocation into cytosol and degradation by the proteasome. Perturbation of this process causes mitophagy, which plays a vital role in the quality control of mitochondria in heart disease. Given that it has been well-studied and summarized in many other reviews $(319,320)$, we do not discuss it here in detail.

NDUFB10, an accessory subunit of complex I, is a substrate of the MIA machinery (CHCHD4/ Mia40) for oxidationdependent protein import into the mitochondrial IMS. Mutation of cysteine 107 of NDUFB10 impaired its mitochondrial import via $\mathrm{CHCHD} 4$ and resulted in complex I assembly defect, led to fatal infantile lactic acidosis and cardiomyopathy in a single-case report of an infant (321).
In addition, some other proteins also showed a protective effect against $\mathrm{I} / \mathrm{R}$ or $\mathrm{H} / \mathrm{R}$ stress through enhancing their translocation from the cytosol to the mitochondria; these include $\alpha$-crystallin $\mathrm{B}$ (cryAB, the major small heat shock protein in cardiomyocytes) via VDAC-Tom20 (322) and DJ-1 via mtHSP70 (246, 323-325).

\section{Other Conditions That Affect Mitochondrial Protein Import Efficiency in Heart Disease}

According to their subcellular spatial arrangement in cardiomyocytes, mitochondria are classified into three groups: subsarcolemmal mitochondria (SSM) existing below the cell membrane, interfibrillar mitochondria (IFM) residing in rows between the myofibrils, and perinuclear mitochondria located at the nuclear poles. Mitochondrial subpopulations vary in structure and function and appear to be influenced disparately in different cardiac pathologies, including I/R, heart failure, aging, exercise, and diabetes mellitus. According to recent studies, the mitochondrial import machinery in IFM of T1DM hearts $(247,326)$ and SSM of T2DM hearts $(248,327)$ were more susceptible to inefficiency. Further, many studies reported the downregulation of mitochondrial importmachinery components in heart disease, such as heart failure, DCM, ischemic cardiomyopathy, diabetic cardiomyopathy, etc. Supplements of corresponding components could partially recover cardiac function.

However, some studies pointed out an enhancement of mitochondrial protein import in aging animals. Craig et al. found mitochondria from senescent animals exhibited a higher import rate of precursors into the matrix than mitochondria from young animals (328). Later studies showed that, although expression of some key import machinery components was upregulated in the aging heart, import efficiency was compromised (238). The mechanism and significance need to be determined in future studies.

In addition, the import rate of matrix-localized proteins was found to be increased in heart of hyperthyroid animals or by T3 treatment (329-332), which was partially mediated by elevated levels of the OM receptor Tom 20 and mtHSP70. Meanwhile, the proteolysis of matrix proteins was unaffected.

\section{CONCLUSION}

Mitochondrial import machinery pathways are involved in various heart diseases, including heart failure, DCM, hypertrophic cardiomyopathy, ischemic cardiomyopathy, and diabetic cardiomyopathy. Mutants of genes encoding components of the mitochondrial import machinery in humans or genetic deficiency of those genes in animals usually cause severe mitochondrial cardiomyopathy and are lethal, highlighting the critical role of mitochondrial import machinery in heart disease. However, compared with neurodegenerative diseases, in which the functions of mitochondrial import machinery are relatively well-studied and established, research in heart disease is still fairly limited. Although many studies 
detected some components of mitochondrial import machinery, most studies simply regarded those components as indicators of mitochondrial content to evaluate mitochondrial biogenesis or mitophagy. The function of mitochondrial import machinery was highly neglected. Actually, even from the perspective of mitochondrial biogenesis or mitophagy, under different stimuli, import machinery components are able to adapt to diverse cellular functions, which are not always proportional to mitochondrial quantity.

Furthermore, our current understanding of mitochondrial import machinery in heart disease is still widely based on experimental evidence from yeast. Nevertheless, recent research in higher eukaryotes has identified more complex and diverse functions in some conserved components of mitochondrial import machinery. Furthermore, with the development of high-throughput sequencing in genomics, transcriptomics, proteomics, and metabolomics, more and more novel import machinery components have been revealed in mammals. The roles of mitochondrial import machinery in heart disease deserve considerable attention, and future studies are urgently needed.

\section{REFERENCES}

1. Dennerlein S, Wang C, Rehling P. Plasticity of mitochondrial translation. Trends Cell Biol. (2017) 27:712-21. doi: 10.1016/j.tcb.2017.05.004

2. Schmidt O, Harbauer AB, Rao S, Eyrich B, Zahedi RP, Stojanovski D, et al. Regulation of mitochondrial protein import by cytosolic kinases. Cell. (2011) 144:227-39. doi: 10.1016/j.cell.2010.12.015

3. Wiedemann $\mathrm{N}$, Pfanner N. Mitochondrial machineries for protein import and assembly. Annu Rev Biochem. (2017) 86:685-714. doi: 10.1146/annurev-biochem-060815-014352

4. Pfanner N, Warscheid B, Wiedemann N. Mitochondrial proteins: from biogenesis to functional networks. Nat Rev Mol Cell Biol. (2019) 20:26784. doi: 10.1038/s41580-018-0092-0

5. Nicolas E, Tricarico R, Savage M, Golemis EA, Hall MJ. Disease-associated genetic variation in human mitochondrial protein import. Am J Hum Genet. (2019) 104:784-801. doi: 10.1016/j.ajhg.2019.03.019

6. Jackson TD, Palmer CS, Stojanovski D. Mitochondrial diseases caused by dysfunctional mitochondrial protein import. Biochem Soc Trans. (2018) 46:1225-38. doi: 10.1042/BST20180239

7. Vogtle FN, Wortelkamp S, Zahedi RP, Becker D, Leidhold C, Gevaert $\mathrm{K}$, et al. Global analysis of the mitochondrial N-proteome identifies a processing peptidase critical for protein stability. Cell. (2009) 139:42839. doi: $10.1016 /$ j.cell.2009.07.045

8. Roise D, Horvath SJ, Tomich JM, Richards JH, Schatz G. A chemically synthesized pre-sequence of an imported mitochondrial protein can form an amphiphilic helix and perturb natural and artificial phospholipid bilayers. EMBO J. (1986) 5:1327-34. doi: 10.1002/j.1460-2075.1986.tb0 4363.x

9. Abe Y, Shodai T, Muto T, Mihara K, Torii H, Nishikawa $\mathrm{S}$, et al. Structural basis of presequence recognition by the mitochondrial protein import receptor Tom20. Cell. (2000) 100:551-60. doi: 10.1016/S0092-8674(00)80691-1

10. van Wilpe S, Ryan MT, Hill K, Maarse AC, Meisinger C, Brix J, et al. Tom22 is a multifunctional organizer of the mitochondrial preprotein translocase. Nature. (1999) 401:485-9. doi: 10.1038/46802

11. Mokranjac D, Neupert W. Cell biology: architecture of a protein entry gate. Nature. (2015) 528:201-2. doi: 10.1038/nature16318

12. Lohret TA, Jensen RE, Kinnally KW. Tim23, a protein import component of the mitochondrial inner membrane, is required for normal activity

\section{AUTHOR CONTRIBUTIONS}

FZ devised the original idea of the work, searched the literature, and wrote the manuscript. M-HZ edited the manuscript. All authors made significant contributions to this work and approved it for publication.

\section{FUNDING}

M-HZ's lab was supported by funding from the following agencies: National Heart, Lung, and Blood Institute (HL079584, HL080499, HL089920, HL110488, HL128014, HL132500, HL137371, and HL142287) and National Cancer Institute (CA213022). M-HZ is the Eminent Scholar in Molecular and Translational Medicine of the Georgia Research Alliance.

\section{ACKNOWLEDGMENTS}

We thank Jian Li for literature search. Yang Wu for the language editing and optimization. Donghong Zhang, Zhixue Liu, and Ping Song for critical reading of the manuscript.

of the multiple conductance channel, MCC. J Cell Biol. (1997) 137:37786. doi: $10.1083 / \mathrm{jcb} .137 .2 .377$

13. Bauer MF, Sirrenberg C, Neupert W, Brunner M. Role of Tim23 as voltage sensor and presequence receptor in protein import into mitochondria. Cell. (1996) 87:33-41. doi: 10.1016/S0092-8674(00)81320-3

14. Dekker PJ, Keil P, Rassow J, Maarse AC, Pfanner N, Meijer M. Identification of MIM23, a putative component of the protein import machinery of the mitochondrial inner membrane. FEBS Lett. (1993) 330:6670. doi: 10.1016/0014-5793(93)80921-G

15. Demishtein-Zohary K, Marom M, Neupert W, Mokranjac D, Azem A. GxxxG motifs hold the TIM23 complex together. FEBS J. (2015) 282:217886. doi: $10.1111 /$ febs.13266

16. Chacinska A, Lind M, Frazier AE, Dudek J, Meisinger C, Geissler A, et al. Mitochondrial presequence translocase: switching between TOM tethering and motor recruitment involves Tim21 and Tim17. Cell. (2005) 120:81729. doi: 10.1016/j.cell.2005.01.011

17. Kang PJ, Ostermann J, Shilling J, Neupert W, Craig EA, Pfanner N. Requirement for hsp70 in the mitochondrial matrix for translocation and folding of precursor proteins. Nature. (1990) 348:137-43. doi: 10.1038/348137a0

18. Horst M, Oppliger W, Rospert S, Schonfeld HJ, Schatz G, Azem A. Sequential action of two hsp70 complexes during protein import into mitochondria. EMBO J. (1997) 16:1842-9. doi: 10.1093/emboj/16.8.1842

19. Demishtein-Zohary K, Gunsel U, Marom M, Banerjee R, Neupert W, Azem A, et al. Role of Tim17 in coupling the import motor to the translocation channel of the mitochondrial presequence translocase. Elife. (2017) 6:22696. doi: 10.7554/eLife.22696

20. Ting SY, Yan NL, Schilke BA, Craig EA. Dual interaction of scaffold protein Tim44 of mitochondrial import motor with channel-forming translocase subunit Tim23. Elife. (2017) 6:23609. doi: 10.7554/eLife.23609

21. Banerjee R, Gladkova C, Mapa K, Witte G, Mokranjac D. Protein translocation channel of mitochondrial inner membrane and matrixexposed import motor communicate via two-domain coupling protein. Elife. (2015) 4:e11897. doi: 10.7554/eLife.11897

22. Sikor M, Mapa K, von Voithenberg LV, Mokranjac D, Lamb DC. Real-time observation of the conformational dynamics of mitochondrial Hsp70 by spFRET. EMBO J. (2013) 32:1639-49. doi: 10.1038/emboj.2013.89

23. Schendzielorz AB, Schulz C, Lytovchenko O, Clancy A, Guiard B, Ieva $\mathrm{R}$, et al. Two distinct membrane potential-dependent steps drive 
mitochondrial matrix protein translocation. J Cell Biol. (2017) 216:8392. doi: $10.1083 / \mathrm{jcb} .201607066$

24. Schulz C, Rehling P. Remodelling of the active presequence translocase drives motor-dependent mitochondrial protein translocation. Nat Commun. (2014) 5:4349. doi: 10.1038/ncomms5349

25. Truscott KN, Kovermann P, Geissler A, Merlin A, Meijer M, Driessen AJ, et al. A presequence- and voltage-sensitive channel of the mitochondrial preprotein translocase formed by Tim23. Nat Struct Biol. (2001) 8:107482. doi: $10.1038 /$ nsb726

26. Malhotra K, Modak A, Nangia S, Daman TH, Gunsel U, Robinson VL, et al. Cardiolipin mediates membrane and channel interactions of the mitochondrial TIM23 protein import complex receptor Tim50. Sci Adv. (2017) 3:e1700532. doi: 10.1126/sciadv.1700532

27. Denkert N, Schendzielorz AB, Barbot M, Versemann L, Richter F, Rehling $\mathrm{P}$, et al. Cation selectivity of the presequence translocase channel Tim23 is crucial for efficient protein import. Elife. (2017) 6:28324. doi: 10.7554/eLife.28324

28. Ramesh A, Peleh V, Martinez-Caballero S, Wollweber F, Sommer F, van der Laan M, et al. A disulfide bond in the TIM23 complex is crucial for voltage gating and mitochondrial protein import. J Cell Biol. (2016) 214:417-31. doi: 10.1083/jcb.201602074

29. Hawlitschek G, Schneider H, Schmidt B, Tropschug M, Hartl FU, Neupert W. Mitochondrial protein import: identification of processing peptidase and of PEP, a processing enhancing protein. Cell. (1988) 53:795806. doi: 10.1016/0092-8674(88)90096-7

30. Neupert W. A perspective on transport of proteins into mitochondria: a myriad of open questions. J Mol Biol. (2015) 427:1135-58. doi: 10.1016/j.jmb.2015.02.001

31. Fukasawa Y, Tsuji J, Fu SC, Tomii K, Horton P, Imai K. MitoFates: improved prediction of mitochondrial targeting sequences and their cleavage sites. Mol Cell Proteomics. (2015) 14:1113-26. doi: 10.1074/mcp.M114.0 43083

32. Varshavsky A. The N-end rule pathway and regulation by proteolysis. Protein Sci. (2011) 20:1298-345. doi: 10.1002/pro.666

33. Veling MT, Reidenbach AG, Freiberger EC, Kwiecien NW, Hutchins $\mathrm{PD}$, Drahnak MJ, et al. Multi-omic mitoprotease profiling defines a role for Oct1p in coenzyme Q production. Mol Cell. (2017) 68:970-77 e11. doi: 10.1016/j.molcel.2017.11.023

34. Vogtle FN, Prinz C, Kellermann J, Lottspeich F, Pfanner N, Meisinger C. Mitochondrial protein turnover: role of the precursor intermediate peptidase Oct1 in protein stabilization. Mol Biol Cell. (2011) 22:213543. doi: 10.1091/mbc.e11-02-0169

35. Ieva R, Schrempp SG, Opalinski L, Wollweber F, Hoss P, Heisswolf $\mathrm{AK}$, et al. Mgr2 functions as lateral gatekeeper for preprotein sorting in the mitochondrial inner membrane. Mol Cell. (2014) 56:641-52. doi: 10.1016/j.molcel.2014.10.010

36. Matta SK, Kumar A, D'Silva P. Mgr2 regulates mitochondrial preprotein import by associating with channel-forming Tim23 subunit. Mol Biol Cell. (2020) 31:1112-23. doi: 10.1091/mbc.E19-12-0677

37. Schendzielorz AB, Bragoszewski P, Naumenko N, Gomkale R, Schulz C, Guiard B, et al. Motor recruitment to the TIM23 channel's lateral gate restricts polypeptide release into the inner membrane. Nat Commun. (2018) 9:4028. doi: 10.1038/s41467-018-06492-8

38. Stiller SB, Hopker J, Oeljeklaus S, Schutze C, Schrempp SG, VentSchmidt J, et al. Mitochondrial OXA translocase plays a major role in biogenesis of inner-membrane proteins. Cell Metab. (2016) 23:9018. doi: 10.1016/j.cmet.2016.04.005

39. Park K, Botelho SC, Hong J, Osterberg M, Kim H. Dissecting stop transfer vs. conservative sorting pathways for mitochondrial inner membrane proteins in vivo. J Biol Chem. (2013) 288:1521-32. doi: 10.1074/jbc.M112.4 09748

40. Bohnert M, Rehling P, Guiard B, Herrmann JM, Pfanner N, van der Laan M. Cooperation of stop-transfer and conservative sorting mechanisms in mitochondrial protein transport. Curr Biol. (2010) 20:122732. doi: 10.1016/j.cub.2010.05.058

41. Herrmann JM, Neupert W, Stuart RA. Insertion into the mitochondrial inner membrane of a polytopic protein, the nuclear-encoded Oxalp. EMBO J. (1997) 16:2217-26. doi: 10.1093/emboj/16.9.2217
42. Hell K, Neupert W, Stuart RA. Oxalp acts as a general membrane insertion machinery for proteins encoded by mitochondrial DNA. EMBO J. (2001) 20:1281-8. doi: 10.1093/emboj/20.6.1281

43. Kiebler M, Pfaller R, Sollner T, Griffiths G, Horstmann H, Pfanner N, et al. Identification of a mitochondrial receptor complex required for recognition and membrane insertion of precursor proteins. Nature. (1990) 348:6106. doi: $10.1038 / 348610 \mathrm{a} 0$

44. Hill K, Model K, Ryan MT, Dietmeier K, Martin F, Wagner R, et al. Tom40 forms the hydrophilic channel of the mitochondrial import pore for preproteins [see comment]. Nature. (1998) 395:516-21. doi: 10.1038/26780

45. Shiota T, Imai K, Qiu J, Hewitt VL, Tan K, Shen HH, et al. Molecular architecture of the active mitochondrial protein gate. Science. (2015) 349:1544-8. doi: 10.1126/science.aac6428

46. Yamano $\mathrm{K}$, Yatsukawa $\mathrm{Y}$, Esaki M, Hobbs AE, Jensen RE, Endo T. Tom 20 and Tom 22 share the common signal recognition pathway in mitochondrial protein import. J Biol Chem. (2008) 283:3799-807. doi: 10.1074/jbc.M708339200

47. Young JC, Hoogenraad NJ, Hartl FU. Molecular chaperones Hsp90 and Hsp70 deliver preproteins to the mitochondrial import receptor Tom70. Cell. (2003) 112:41-50. doi: 10.1016/S0092-8674(02)01250-3

48. Bhangoo MK, Tzankov S, Fan AC, Dejgaard K, Thomas DY, Young JC. Multiple $40-\mathrm{kDa}$ heat-shock protein chaperones function in Tom70-dependent mitochondrial import. Mol Biol Cell. (2007) 18:3414-28. doi: 10.1091/mbc.e07-01-0088

49. Wu Y, Sha B. Crystal structure of yeast mitochondrial outer membrane translocon member Tom70p. Nat Struct Mol Biol. (2006) 13:58993. doi: $10.1038 / \mathrm{nsmb} 1106$

50. Backes S, Hess S, Boos F, Woellhaf MW, Godel S, Jung M, et al. Tom70 enhances mitochondrial preprotein import efficiency by binding to internal targeting sequences. J Cell Biol. (2018) 217:1369-82. doi: 10.1083/jcb.201708044

51. Melin J, Kilisch M, Neumann P, Lytovchenko O, Gomkale R, Schendzielorz A, et al. A presequence-binding groove in Tom70 supports import of Mdl1 into mitochondria. Biochim Biophys Acta. (2015) 1853:18509. doi: 10.1016/j.bbamcr.2015.04.021

52. Yamamoto H, Fukui K, Takahashi H, Kitamura S, Shiota T, Terao K, et al. Roles of Tom70 in import of presequence-containing mitochondrial proteins. J Biol Chem. (2009) 284:31635-46. doi: 10.1074/jbc.M109.041756

53. Bayrhuber M, Meins T, Habeck M, Becker S, Giller K, Villinger S, et al. Structure of the human voltage-dependent anion channel. Proc Natl Acad Sci USA. (2008) 105:15370-5. doi: 10.1073/pnas.0808115105

54. Qiu J, Wenz LS, Zerbes RM, Oeljeklaus S, Bohnert M, Stroud DA, et al. Coupling of mitochondrial import and export translocases by receptor-mediated supercomplex formation. Cell. (2013) 154:596-608. doi: 10.1016/j.cell.2013.06.033

55. Lackey SW, Taylor RD, Go NE, Wong A, Sherman EL, Nargang FE. Evidence supporting the 19 beta-strand model for Tom40 from cysteine scanning and protease site accessibility studies. J Biol Chem. (2014) 289:2164050. doi: 10.1074/jbc.M114.578765

56. Esaki M, Kanamori T, Nishikawa S, Shin I, Schultz PG, Endo T. Tom 40 protein import channel binds to non-native proteins and prevents their aggregation. Nat Struct Biol. (2003) 10:988-94. doi: 10.1038/nsb1008

57. Melin J, Schulz C, Wrobel L, Bernhard O, Chacinska A, Jahn O, et al. Presequence recognition by the tom 40 channel contributes to precursor translocation into the mitochondrial matrix. Mol Cell Biol. (2014) 34:347385. doi: 10.1128/MCB.00433-14

58. Yamano K, Tanaka-Yamano S, Endo T. Tom7 regulates Mdm10-mediated assembly of the mitochondrial import channel protein Tom40. J Biol Chem. (2010) 285:41222-31. doi: 10.1074/jbc.M110.163238

59. Dietmeier K, Honlinger A, Bomer U, Dekker PJ, Eckerskorn C, Lottspeich F, et al. Tom5 functionally links mitochondrial preprotein receptors to the general import pore. Nature. (1997) 388:195-200. doi: 10.1038/40663

60. Gornicka A, Bragoszewski P, Chroscicki P, Wenz LS, Schulz C, Rehling P, et al. discrete pathway for the transfer of intermembrane space proteins across the outer membrane of mitochondria. Mol Biol Cell. (2014) 25:39994009. doi: 10.1091/mbc.e14-06-1155

61. Kurz M, Martin H, Rassow J, Pfanner N, Ryan MT. Biogenesis of Tim proteins of the mitochondrial carrier import pathway: differential targeting 
mechanisms and crossing over with the main import pathway. Mol Biol Cell. (1999) 10:2461-74. doi: 10.1091/mbc.10.7.2461

62. Schulz C, Schendzielorz A, Rehling P. Unlocking the presequence import pathway. Trends Cell Biol. (2015) 25:265-75. doi: 10.1016/j.tcb.2014.12.001

63. Rahman B, Kawano S, Yunoki-Esaki K, Anzai T, Endo T, NMR. analyses on the interactions of the yeast Tim50 C-terminal region with the presequence and Tim50 core domain. FEBS Lett. (2014) 588:67884. doi: 10.1016/j.febslet.2013.12.037

64. Martinez-Caballero S, Grigoriev SM, Herrmann JM, Campo ML, Kinnally KW. Tim $17 \mathrm{p}$ regulates the twin pore structure and voltage gating of the mitochondrial protein import complex TIM23. J Biol Chem. (2007) 282:3584-93. doi: 10.1074/jbc.M607551200

65. van der Laan M, Wiedemann N, Mick DU, Guiard B, Rehling P, Pfanner N, et al. role for Tim21 in membrane-potential-dependent preprotein sorting in mitochondria. Curr Biol. (2006) 16:2271-6. doi: 10.1016/j.cub.2006.10.025

66. Meinecke M, Wagner R, Kovermann P, Guiard B, Mick DU, Hutu DP, et al. Tim50 maintains the permeability barrier of the mitochondrial inner membrane. Science. (2006) 312:1523-6. doi: 10.1126/science.1127628

67. Tamura Y, Harada Y, Shiota T, Yamano K, Watanabe K, Yokota M, et al. Tim23-Tim50 pair coordinates functions of translocators and motor proteins in mitochondrial protein import. J Cell Biol. (2009) 184:12941. doi: $10.1083 /$ jcb. 200808068

68. Mokranjac D, Sichting M, Popov-Celeketic D, Mapa K, GevorkyanAirapetov L, Zohary K, et al. Role of Tim50 in the transfer of precursor proteins from the outer to the inner membrane of mitochondria. Mol Biol Cell. (2009) 20:1400-7. doi: 10.1091/mbc.e08-09-0934

69. Gevorkyan-Airapetov L, Zohary K, Popov-Celeketic D, Mapa K, Hell K, Neupert W, et al. Interaction of Tim 23 with Tim50 is essential for protein translocation by the mitochondrial TIM23 complex. J Biol Chem. (2009) 284:4865-72. doi: 10.1074/jbc.M807041200

70. Rainbolt TK, Atanassova N, Genereux JC, Wiseman RL. Stressregulated translational attenuation adapts mitochondrial protein import through Tim17A degradation. Cell Metab. (2013) 18:908-19. doi: 10.1016/j.cmet.2013.11.006

71. Wrobel L, Sokol AM, Chojnacka M, Chacinska A. The presence of disulfide bonds reveals an evolutionarily conserved mechanism involved in mitochondrial protein translocase assembly. Sci Rep. (2016) 6:27484. doi: 10.1038/srep27484

72. Lytovchenko O, Melin J, Schulz C, Kilisch M, Hutu DP, Rehling P. Signal recognition initiates reorganization of the presequence translocase during protein import. EMBO J. (2013) 32:886-98. doi: 10.1038/emboj.2013.23

73. Mokranjac D, Popov-Celeketic D, Hell K, Neupert W. Role of Tim21 in mitochondrial translocation contact sites. J Biol Chem. (2005) 280:2343740. doi: 10.1074/jbc.C500135200

74. Albrecht R, Rehling P, Chacinska A, Brix J, Cadamuro SA, Volkmer $\mathrm{R}$, et al. The Tim21 binding domain connects the preprotein translocases of both mitochondrial membranes. EMBO Rep. (2006) 7:1233-8. doi: 10.1038/sj.embor.7400828

75. Wiedemann N, van der Laan M, Hutu DP, Rehling P, Pfanner N. Sorting switch of mitochondrial presequence translocase involves coupling of motor module to respiratory chain. J Cell Biol. (2007) 179:111522. doi: $10.1083 /$ jcb. 200709087

76. Gebert M, Schrempp SG, Mehnert CS, Heisswolf AK, Oeljeklaus $\mathrm{S}$, Ieva R, et al. Mgr2 promotes coupling of the mitochondrial presequence translocase to partner complexes. J Cell Biol. (2012) 197:595-604. doi: 10.1083/jcb.201110047

77. Martin J, Mahlke K, Pfanner N. Role of an energized inner membrane in mitochondrial protein import. Delta psi drives the movement of presequences. J Biol Chem. (1991) 266:180517. doi: $10.1016 / \mathrm{S} 0021-9258(18) 55235-2$

78. Turakhiya U, von der Malsburg K, Gold VAM, Guiard B, Chacinska A, van der Laan $\mathrm{M}$, et al. Protein import by the mitochondrial presequence translocase in the absence of a membrane potential. J Mol Biol. (2016) 428:1041-52. doi: 10.1016/j.jmb.2016.01.020

79. Popov-Celeketic D, Mapa K, Neupert W, Mokranjac D. Active remodelling of the TIM23 complex during translocation of preproteins into mitochondria. EMBO J. (2008) 27:1469-80. doi: 10.1038/emboj.2008.79
80. Ting SY, Schilke BA, Hayashi M, Craig EA. Architecture of the TIM23 inner mitochondrial translocon and interactions with the matrix import motor. $J$ Biol Chem. (2014) 289:28689-96. doi: 10.1074/jbc.M114.588152

81. Dekker PJ, Pfanner N. Role of mitochondrial GrpE and phosphate in the ATPase cycle of matrix Hsp70. J Mol Biol. (1997) 270:3217. doi: 10.1006/jmbi.1997.1131

82. Mokranjac D, Bourenkov G, Hell K, Neupert W, Groll M. Structure and function of Tim14 and Tim16, the J and J-like components of the mitochondrial protein import motor. EMBO J. (2006) 25:467585. doi: 10.1038/sj.emboj.7601334

83. D'Silva PR, Schilke B, Hayashi M, Craig EA. Interaction of the Jprotein heterodimer Pam18/Pam16 of the mitochondrial import motor with the translocon of the inner membrane. Mol Biol Cell. (2008) 19:42432. doi: 10.1091/mbc.e07-08-0748

84. Kozany C, Mokranjac D, Sichting M, Neupert W, Hell K. The J domain-related cochaperone Tim16 is a constituent of the mitochondrial TIM23 preprotein translocase. Nat Struct Mol Biol. (2004) 11:23441. doi: $10.1038 / \mathrm{nsmb} 734$

85. Frazier AE, Dudek J, Guiard B, Voos W, Li Y, Lind M, et al. Pam16 has an essential role in the mitochondrial protein import motor. Nat Struct Mol Biol. (2004) 11:226-33. doi: 10.1038/nsmb735

86. Li Y, Dudek J, Guiard B, Pfanner N, Rehling P, Voos W. The presequence translocase-associated protein import motor of mitochondria. Pam16 functions in an antagonistic manner to Pam18. J Biol Chem. (2004) 279:38047-54. doi: 10.1074/jbc.M404319200

87. van der Laan M, Chacinska A, Lind M, Perschil I, Sickmann A, Meyer HE, et al. Pam17 is required for architecture and translocation activity of the mitochondrial protein import motor. Mol Cell Biol. (2005) 25:744958. doi: 10.1128/MCB.25.17.7449-7458.2005

88. Taylor AB, Smith BS, Kitada S, Kojima K, Miyaura H, Otwinowski Z, et al. Crystal structures of mitochondrial processing peptidase reveal the mode for specific cleavage of import signal sequences. Structure. (2001) 9:615-25. doi: 10.1016/S0969-2126(01)00621-9

89. Naamati A, Regev-Rudzki N, Galperin S, Lill R, Pines O. Dual targeting of $\mathrm{Nfs} 1$ and discovery of its novel processing enzyme, Icp55. J Biol Chem. (2009) 284:30200-8. doi: 10.1074/jbc.M109.034694

90. Gakh O, Cavadini P, Isaya G. Mitochondrial processing peptidases. Biochim Biophys Acta. (2002) 1592:63-77. doi: 10.1016/S0167-4889(02)00265-3

91. Koppen M, Langer T. Protein degradation within mitochondria: versatile activities of AAA proteases and other peptidases. Crit Rev Biochem Mol Biol. (2007) 42:221-42. doi: 10.1080/10409230701380452

92. Ostermann J, Horwich AL, Neupert W, Hartl FU. Protein folding in mitochondria requires complex formation with hsp60 and ATP hydrolysis. Nature. (1989) 341:125-30. doi: 10.1038/341125a0

93. Johnson KA, Bhushan S, Stahl A, Hallberg BM, Frohn A, Glaser E, et al. The closed structure of presequence protease PreP forms a unique 10,000 Angstroms3 chamber for proteolysis. EMBO J. (2006) 25:197786. doi: 10.1038/sj.emboj.7601080

94. Mossmann D, Vogtle FN, Taskin AA, Teixeira PF, Ring J, Burkhart $\mathrm{JM}$, et al. Amyloid-beta peptide induces mitochondrial dysfunction by inhibition of preprotein maturation. Cell Metab. (2014) 20:6629. doi: 10.1016/j.cmet.2014.07.024

95. He S, Fox TD. Membrane translocation of mitochondrially coded Cox2p: distinct requirements for export of $\mathrm{N}$ and $\mathrm{C}$ termini and dependence on the conserved protein Oxalp. Mol Biol Cell. (1997) 8:144960. doi: 10.1091/mbc.8.8.1449

96. Pfeffer S, Woellhaf MW, Herrmann JM, Forster F. Organization of the mitochondrial translation machinery studied in situ by cryoelectron tomography. Nat Commun. (2015) 6:6019. doi: 10.1038/ncomms7019

97. Ott M, Herrmann JM. Co-translational membrane insertion of mitochondrially encoded proteins. Biochim Biophys Acta. (2010) 1803:767-75. doi: 10.1016/j.bbamcr.2009.11.010

98. Hell K, Herrmann JM, Pratje E, Neupert W, Stuart RA. Oxalp, an essential component of the N-tail protein export machinery in mitochondria. Proc Natl Acad Sci USA. (1998) 95:2250-5. doi: 10.1073/pnas.95.5.2250

99. Hartl FU, Schmidt B, Wachter E, Weiss H, Neupert W. Transport into mitochondria and intramitochondrial sorting of the $\mathrm{Fe} / \mathrm{S}$ 
protein of ubiquinol-cytochrome c reductase. Cell. (1986) 47:939-51. doi: 10.1016/0092-8674(86)90809-3

100. Rojo EE, Stuart RA, Neupert W. Conservative sorting of F0-ATPase subunit 9: export from matrix requires delta $\mathrm{pH}$ across inner membrane and matrix ATP. EMBO J. (1995) 14:3445-51. doi: 10.1002/j.1460-2075.1995.tb07350.x

101. Hildenbeutel M, Theis M, Geier M, Haferkamp I, Neuhaus HE, Herrmann $\mathrm{JM}$, et al. The membrane insertase Oxal is required for efficient import of carrier proteins into mitochondria. J Mol Biol. (2012) 423:5909. doi: 10.1016/j.jmb.2012.07.018

102. Hansen KG, Herrmann JM. Transport of proteins into mitochondria. Protein J. (2019) 38:330-42. doi: 10.1007/s10930-019-09819-6

103. Endres M, Neupert W, Brunner M. Transport of the ADP/ATP carrier of mitochondria from the TOM complex to the TIM2254 complex. EMBO J. (1999) 18:3214-21. doi: 10.1093/emboj/18.12.3214

104. Brix J, Rudiger S, Bukau B, Schneider-Mergener J, Pfanner N. Distribution of binding sequences for the mitochondrial import receptors Tom20, Tom22, and Tom70 in a presequence-carrying preprotein and a non-cleavable preprotein. J Biol Chem. (1999) 274:16522-30. doi: 10.1074/jbc.274.23.16522

105. Faou P, Hoogenraad NJ. Tom34: a cytosolic cochaperone of the Hsp90/Hsp70 protein complex involved in mitochondrial protein import. Biochim Biophys Acta. (2012) 1823:348-57. doi: 10.1016/j.bbamcr.2011.12.001

106. Gava LM, Goncalves DC, Borges JC, Ramos CH. Stoichiometry and thermodynamics of the interaction between the C-terminus of human $90 \mathrm{kDa}$ heat shock protein $\mathrm{Hsp} 90$ and the mitochondrial translocase of outer membrane Tom70. Arch Biochem Biophys. (2011) 513:11925. doi: 10.1016/j.abb.2011.06.015

107. Baker MJ, Webb CT, Stroud DA, Palmer CS, Frazier AE, Guiard B, et al. Structural and functional requirements for activity of the Tim9-Tim10 complex in mitochondrial protein import. Mol Biol Cell. (2009) 20:76979. doi: $10.1091 / \mathrm{mbc}$.e08-09-0903

108. Koehler CM, Merchant S, Oppliger W, Schmid K, Jarosch E, Dolfini L, et al. Tim9p, an essential partner subunit of Tim10p for the import of mitochondrial carrier proteins. EMBO J. (1998) 17:647786. doi: $10.1093 / \mathrm{emboj} / 17.22 .6477$

109. Sirrenberg C, Endres M, Folsch H, Stuart RA, Neupert W, Brunner M. Carrier protein import into mitochondria mediated by the intermembrane proteins Tim10/Mrs11 and Tim12/Mrs5. Nature. (1998) 391:912-5. doi: 10.1038/36136

110. Weinhaupl K, Lindau C, Hessel A, Wang Y, Schutze C, Jores T, et al. Structural basis of membrane protein chaperoning through the mitochondrial intermembrane space. Cell. (2018) 175:1365-79 e25. doi: 10.1016/j.cell.2018.10.039

111. Sirrenberg C, Bauer MF, Guiard B, Neupert W, Brunner M. Import of carrier proteins into the mitochondrial inner membrane mediated by Tim 22 . Nature. (1996) 384:582-5. doi: 10.1038/384582a0

112. Koehler CM, Jarosch E, Tokatlidis K, Schmid K, Schweyen RJ, Schatz G. Import of mitochondrial carriers mediated by essential proteins of the intermembrane space. Science. (1998) 279:369-73. doi: 10.1126/science.279.5349.369

113. Okamoto H, Miyagawa A, Shiota T, Tamura Y, Endo T. Intramolecular disulfide bond of Tim22 protein maintains integrity of the TIM22 complex in the mitochondrial inner membrane. J Biol Chem. (2014) 289:482738. doi: $10.1074 /$ jbc.M1 13.543264

114. Wrobel L, Trojanowska A, Sztolsztener ME, Chacinska A. Mitochondrial protein import: Mia40 facilitates Tim22 translocation into the inner membrane of mitochondria. Mol Biol Cell. (2013) 24:543-54. doi: 10.1091/mbc.e12-09-0649

115. Rehling P, Model K, Brandner K, Kovermann P, Sickmann A, Meyer HE, et al. Protein insertion into the mitochondrial inner membrane by a twin-pore translocase. Science. (2003) 299:1747-51. doi: 10.1126/science.10 80945

116. Kerscher O, Holder J, Srinivasan M, Leung RS, Jensen RE. The Tim54pTim22p complex mediates insertion of proteins into the mitochondrial inner membrane. J Cell Biol. (1997) 139:1663-75. doi: 10.1083/jcb.13 9.7.1663

117. Li J, Qian X, Hu J, Sha B. Molecular chaperone Hsp70/Hsp90 prepares the mitochondrial outer membrane translocon receptor Tom71 for preprotein loading. J Biol Chem. (2009) 284:23852-9. doi: 10.1074/jbc.M109.023986
118. Wiedemann N, Pfanner N, Ryan MT. The three modules of ADP/ATP carrier cooperate in receptor recruitment and translocation into mitochondria. EMBO J. (2001) 20:951-60. doi: 10.1093/emboj/20.5.951

119. Curran SP, Leuenberger D, Schmidt E, Koehler CM. The role of the Tim8p-Tim13p complex in a conserved import pathway for mitochondrial polytopic inner membrane proteins. J Cell Biol. (2002) 158:101727. doi: $10.1083 /$ jcb. 200205124

120. Webb CT, Gorman MA, Lazarou M, Ryan MT, Gulbis JM. Crystal structure of the mitochondrial chaperone TIM910 reveals a six-bladed alpha-propeller. Mol Cell. (2006) 21:123-33. doi: 10.1016/j.molcel.2005.11.010

121. Curran SP, Leuenberger D, Oppliger W, Koehler CM. The Tim9p-Tim10p complex binds to the transmembrane domains of the ADP/ATP carrier. EMBO J. (2002) 21:942-53. doi: 10.1093/emboj/21.5.942

122. Davis AJ, Alder NN, Jensen RE, Johnson AE. The Tim $9 p / 10 p$ and Tim8p/13p complexes bind to specific sites on Tim23p during mitochondrial protein import. Mol Biol Cell. (2007) 18:475-86. doi: 10.1091/mbc.e06-06-0546

123. Gebert N, Chacinska A, Wagner K, Guiard B, Koehler CM, Rehling $\mathrm{P}$, et al. Assembly of the three small Tim proteins precedes docking to the mitochondrial carrier translocase. EMBO Rep. (2008) 9:54854. doi: 10.1038/embor.2008.49

124. Wagner K, Gebert N, Guiard B, Brandner K, Truscott KN, Wiedemann $\mathrm{N}$, et al. The assembly pathway of the mitochondrial carrier translocase involves four preprotein translocases. Mol Cell Biol. (2008) 28:425160. doi: 10.1128/MCB.02216-07

125. Lionaki E, de Marcos Lousa C, Baud C, Vougioukalaki M, Panayotou G, Tokatlidis K. The essential function of Tim12 in vivo is ensured by the assembly interactions of its C-terminal domain. J Biol Chem. (2008) 283:15747-53. doi: 10.1074/jbc.M800350200

126. Gebert N, Gebert M, Oeljeklaus S, von der Malsburg K, Stroud DA, Kulawiak $B$, et al. Dual function of Sdh3 in the respiratory chain and TIM22 protein translocase of the mitochondrial inner membrane. Mol Cell. (2011) 44:8118. doi: 10.1016/j.molcel.2011.09.025

127. Kulawiak B, Hopker J, Gebert M, Guiard B, Wiedemann N, Gebert N. The mitochondrial protein import machinery has multiple connections to the respiratory chain. Biochim Biophys Acta. (2013) 1827:61226. doi: 10.1016/j.bbabio.2012.12.004

128. Durigon R, Wang Q, Ceh Pavia E, Grant CM, Lu H. Cytosolic thioredoxin system facilitates the import of mitochondrial small Tim proteins. EMBO Rep. (2012) 13:916-22. doi: 10.1038/embor.2012.116

129. Allen S, Balabanidou V, Sideris DP, Lisowsky T, Tokatlidis K. Erv1 mediates the Mia40-dependent protein import pathway and provides a functional link to the respiratory chain by shuttling electrons to cytochrome c. J Mol Biol. (2005) 353:937-44. doi: 10.1016/j.jmb.2005.08.049

130. Mesecke N, Terziyska N, Kozany C, Baumann F, Neupert W, Hell $\mathrm{K}$, et al. disulfide relay system in the intermembrane space of mitochondria that mediates protein import. Cell. (2005) 121:1059-69. doi: 10.1016/j.cell.2005.04.011

131. Hell K. The Erv1-Mia40 disulfide relay system in the intermembrane space of mitochondria. Biochim Biophys Acta. (2008) 1783:6019. doi: 10.1016/j.bbamcr.2007.12.005

132. Rissler M, Wiedemann N, Pfannschmidt S, Gabriel K, Guiard B, Pfanner $\mathrm{N}$, et al. The essential mitochondrial protein Ervl cooperates with Mia40 in biogenesis of intermembrane space proteins. J Mol Biol. (2005) 353:48592. doi: $10.1016 /$ j.jmb.2005.08.051

133. Chacinska A, Pfannschmidt S, Wiedemann N, Kozjak V, Sanjuan Szklarz LK, Schulze-Specking A, et al. Essential role of Mia40 in import and assembly of mitochondrial intermembrane space proteins. EMBO J. (2004) 23:373546. doi: 10.1038/sj.emboj.7600389

134. Terziyska N, Grumbt B, Kozany C, Hell K. Structural and functional roles of the conserved cysteine residues of the redox-regulated import receptor Mia40 in the intermembrane space of mitochondria. J Biol Chem. (2009) 284:1353-63. doi: 10.1074/jbc.M805035200

135. Banci L, Bertini I, Cefaro C, Cenacchi L, Ciofi-Baffoni S, Felli IC, et al. Molecular chaperone function of Mia40 triggers consecutive induced folding steps of the substrate in mitochondrial protein import. Proc Natl Acad Sci USA. (2010) 107:20190-5. doi: 10.1073/pnas.1010095107

136. von der Malsburg K, Muller JM, Bohnert M, Oeljeklaus S, Kwiatkowska P, Becker T, et al. Dual role of mitofilin in mitochondrial 
membrane organization and protein biogenesis. Dev Cell. (2011) 21:694-707. doi: 10.1016/j.devcel.2011.08.026

137. Weckbecker D, Longen S, Riemer J, Herrmann JM. Atp23 biogenesis reveals a chaperone-like folding activity of Mia40 in the IMS of mitochondria. EMBO J. (2012) 31:4348-58. doi: 10.1038/emboj.2012.263

138. Peleh V, Cordat E, Herrmann JM. Mia40 is a trans-site receptor that drives protein import into the mitochondrial intermembrane space by hydrophobic substrate binding. Elife. (2016) 5:16177. doi: 10.7554/eLife.16177

139. Milenkovic D, Ramming T, Muller JM, Wenz LS, Gebert N, SchulzeSpecking A, et al. Identification of the signal directing Tim 9 and Tim10 into the intermembrane space of mitochondria. Mol Biol Cell. (2009) 20:25309. doi: 10.1091/mbc.e08-11-1108

140. Sideris DP, Petrakis N, Katrakili N, Mikropoulou D, Gallo A, Ciofi-Baffoni $\mathrm{S}$, et al. A novel intermembrane space-targeting signal docks cysteines onto Mia40 during mitochondrial oxidative folding. J Cell Biol. (2009) 187:100722. doi: $10.1083 /$ jcb.200905134

141. Bien M, Longen S, Wagener N, Chwalla I, Herrmann JM, Riemer J. Mitochondrial disulfide bond formation is driven by intersubunit electron transfer in Erv1 and proofread by glutathione. Mol Cell. (2010) 37:51628. doi: 10.1016/j.molcel.2010.01.017

142. Bihlmaier K, Mesecke N, Terziyska N, Bien M, Hell K, Herrmann JM. The disulfide relay system of mitochondria is connected to the respiratory chain. J Cell Biol. (2007) 179:389-95. doi: 10.1083/jcb.200707123

143. Dabir DV, Leverich EP, Kim SK, Tsai FD, Hirasawa M, Knaff DB, et al. role for cytochrome $\mathrm{c}$ and cytochrome c peroxidase in electron shuttling from Erv1. EMBO J. (2007) 26:4801-11. doi: 10.1038/sj.emboj.7601909

144. Kawano S, Yamano K, Naoe M, Momose T, Terao K, Nishikawa S, et al. Structural basis of yeast Tim40/Mia40 as an oxidative translocator in the mitochondrial intermembrane space. Proc Natl Acad Sci USA. (2009) 106:14403-7. doi: 10.1073/pnas.0901793106

145. Longen S, Woellhaf MW, Petrungaro C, Riemer J, Herrmann JM. The disulfide relay of the intermembrane space oxidizes the ribosomal subunit mrp10 on its transit into the mitochondrial matrix. Dev Cell. (2014) 28:3042. doi: 10.1016/j.devcel.2013.11.007

146. Jores T, Klinger A, Gross LE, Kawano S, Flinner N, Duchardt-Ferner E, et al. Characterization of the targeting signal in mitochondrial betabarrel proteins. Nat Commun. (2016) 7:12036. doi: 10.1038/ncomms 12036

147. Klein A, Israel L, Lackey SW, Nargang FE, Imhof A, Baumeister $\mathrm{W}$, et al. Characterization of the insertase for beta-barrel proteins of the outer mitochondrial membrane. J Cell Biol. (2012) 199:599611. doi: $10.1083 /$ jcb.201207161

148. Wiedemann N, Kozjak V, Chacinska A, Schonfisch B, Rospert S, Ryan MT, et al. Machinery for protein sorting and assembly in the mitochondrial outer membrane. Nature. (2003) 424:565-71. doi: 10.1038/nature01753

149. Paschen SA, Waizenegger T, Stan T, Preuss M, Cyrklaff M, Hell K, et al. Evolutionary conservation of biogenesis of beta-barrel membrane proteins. Nature. (2003) 426:862-6. doi: 10.1038/nature02208

150. Hohr AIC, Lindau C, Wirth C, Qiu J, Stroud DA, Kutik S, et al. Membrane protein insertion through a mitochondrial beta-barrel gate. Science. (2018) 359:aah6834. doi: 10.1126/science.aah6834

151. Kutik S, Stojanovski D, Becker L, Becker T, Meinecke M, Kruger V, et al. Dissecting membrane insertion of mitochondrial beta-barrel proteins. Cell. (2008) 132:1011-24. doi: 10.1016/j.cell.2008.01.028

152. Wenz LS, Ellenrieder L, Qiu J, Bohnert M, Zufall N, van der Laan M, et al. Sam37 is crucial for formation of the mitochondrial TOM-SAM supercomplex, thereby promoting beta-barrel biogenesis. J Cell Biol. (2015) 210:1047-54. doi: 10.1083/jcb.201504119

153. Popov-Celeketic J, Waizenegger T, Rapaport D. Mim1 functions in an oligomeric form to facilitate the integration of Tom20 into the mitochondrial outer membrane. J Mol Biol. (2008) 376:671-80. doi: 10.1016/j.jmb.2007.12.006

154. Hulett JM, Lueder F, Chan NC, Perry AJ, Wolynec P, Likic VA, et al. The transmembrane segment of Tom 20 is recognized by Mim1 for docking to the mitochondrial TOM complex. J Mol Biol. (2008) 376:694704. doi: 10.1016/j.jmb.2007.12.021

155. Papic D, Krumpe K, Dukanovic J, Dimmer KS, Rapaport D. Multispan mitochondrial outer membrane protein Ugol follows a unique Mim1-dependent import pathway. J Cell Biol. (2011) 194:397-405. doi: 10.1083/jcb.201102041

156. Becker T, Wenz LS, Kruger V, Lehmann W, Muller JM, Goroncy L, et al. The mitochondrial import protein Mim1 promotes biogenesis of multispanning outer membrane proteins. J Cell Biol. (2011) 194:38795. doi: $10.1083 /$ jcb. 201102044

157. Kruger V, Becker T, Becker L, Montilla-Martinez M, Ellenrieder L, Vogtle FN, et al. Identification of new channels by systematic analysis of the mitochondrial outer membrane. J Cell Biol. (2017) 216:348595. doi: $10.1083 /$ jcb. 201706043

158. Dimmer KS, Papic D, Schumann B, Sperl D, Krumpe K, Walther DM, et al. A crucial role for Mim2 in the biogenesis of mitochondrial outer membrane proteins. J Cell Sci. (2012) 125:3464-73. doi: 10.1242/jcs.103804

159. Gupta A, Becker T. Mechanisms and pathways of mitochondrial outer membrane protein biogenesis. Biochim Biophys Acta Bioenerg. (2021) 1862:148323. doi: 10.1016/j.bbabio.2020.148323

160. Keskin A, Akdogan E, Dunn CD. Evidence for amino acid snorkeling from a high-resolution, in vivo analysis of Fis1 tail-anchor insertion at the mitochondrial outer membrane. Genetics. (2017) 205:691-705. doi: 10.1534/genetics.116.196428

161. Vogtle FN, Keller M, Taskin AA, Horvath SE, Guan XL, Prinz C, et al. The fusogenic lipid phosphatidic acid promotes the biogenesis of mitochondrial outer membrane protein Ugo1. J Cell Biol. (2015) 210:95160. doi: $10.1083 /$ jcb. 201506085

162. Sauerwald J, Jores T, Eisenberg-Bord M, Chuartzman SG, Schuldiner M, Rapaport D. Genome-wide screens in saccharomyces cerevisiae highlight a role for cardiolipin in biogenesis of mitochondrial outer membrane multispan proteins. Mol Cell Biol. (2015) 35:3200-11. doi: 10.1128/MCB.00107-15

163. Haynes CM, Ron D. The mitochondrial UPR - protecting organelle protein homeostasis. J Cell Sci. (2010) 123:3849-55. doi: 10.1242/jcs.075119

164. Topf U, Suppanz I, Samluk L, Wrobel L, Boser A, Sakowska P, et al. Quantitative proteomics identifies redox switches for global translation modulation by mitochondrially produced reactive oxygen species. Nat Commun. (2018) 9:324. doi: 10.1038/s41467-017-02694-8

165. Mehnert CS, Rampelt H, Gebert M, Oeljeklaus S, Schrempp SG, Kochbeck $\mathrm{L}$, et al. The mitochondrial ADP/ATP carrier associates with the inner membrane presequence translocase in a stoichiometric manner. J Biol Chem. (2014) 289:27352-62. doi: 10.1074/jbc.M114.556498

166. Dennerlein S, Oeljeklaus S, Jans D, Hellwig C, Bareth B, Jakobs S, et al. MITRAC7 acts as a COX1-specific chaperone and reveals a checkpoint during cytochrome c oxidase assembly. Cell Rep. (2015) 12:164455. doi: 10.1016/j.celrep.2015.08.009

167. Mick DU, Dennerlein S, Wiese H, Reinhold R, Pacheu-Grau D, Lorenzi I, et al. MITRAC links mitochondrial protein translocation to respiratorychain assembly and translational regulation. Cell. (2012) 151:152841. doi: 10.1016/j.cell.2012.11.053

168. Richter-Dennerlein R, Oeljeklaus S, Lorenzi I, Ronsor C, Bareth $\mathrm{B}$, Schendzielorz $\mathrm{AB}$, et al. Mitochondrial protein synthesis adapts to influx of nuclear-encoded protein. Cell. (2016) 167:471-83 e10. doi: 10.1016/j.cell.2016.09.003

169. Shpilka T, Haynes CM. The mitochondrial UPR: mechanisms, physiological functions and implications in ageing. Nat Rev Mol Cell Biol. (2018) 19:10920. doi: 10.1038/nrm.2017.110

170. Nargund AM, Pellegrino MW, Fiorese CJ, Baker BM, Haynes CM. Mitochondrial import efficiency of ATFS-1 regulates mitochondrial UPR activation. Science. (2012) 337:587-90. doi: 10.1126/science.1223560

171. Rolland SG, Schneid S, Schwarz M, Rackles E, Fischer C, Haeussler S, et al. Compromised mitochondrial protein import acts as a signal for UPR(mt). Cell Rep. (2019) 28:1659-69 e5. doi: 10.1016/j.celrep.2019.07.049

172. Wrobel L, Topf U, Bragoszewski P, Wiese S, Sztolsztener ME, Oeljeklaus S, et al. Mistargeted mitochondrial proteins activate a proteostatic response in the cytosol. Nature. (2015) 524:485-8. doi: 10.1038/nature14951

173. Wang X, Chen XJ. A cytosolic network suppressing mitochondriamediated proteostatic stress and cell death. Nature. (2015) 524:4814. doi: 10.1038/nature14859

174. Jin SM, Lazarou M, Wang C, Kane LA, Narendra DP, Youle RJ. Mitochondrial membrane potential regulates PINK1 import 
and proteolytic destabilization by PARL. J Cell Biol. (2010) 191:933-42. doi: 10.1083/jcb.201008084

175. Yamano K, Youle RJ. PINK1 is degraded through the N-end rule pathway. Autophagy. (2013) 9:1758-69. doi: 10.4161/auto.24633

176. Lazarou M, Jin SM, Kane LA, Youle RJ. Role of PINK1 binding to the TOM complex and alternate intracellular membranes in recruitment and activation of the E3 ligase Parkin. Dev Cell. (2012) 22:32033. doi: $10.1016 /$ j.devcel.2011.12.014

177. Kane LA, Lazarou M, Fogel AI Li Y, Yamano K, Sarraf SA, Banerjee S, et al. PINK1 phosphorylates ubiquitin to activate Parkin E3 ubiquitin ligase activity. J Cell Biol. (2014) 205:143-53. doi: 10.1083/jcb.201402104

178. Ruan L, Zhou C, Jin E, Kucharavy A, Zhang Y, Wen Z, et al. Cytosolic proteostasis through importing of misfolded proteins into mitochondria. Nature. (2017) 543:443-46. doi: 10.1038/nature21695

179. Wagner I, Arlt H, van Dyck L, Langer T, Neupert W. Molecular chaperones cooperate with PIM1 protease in the degradation of misfolded proteins in mitochondria. EMBO J. (1994) 13:5135-45. doi: 10.1002/j.1460-2075.1994.tb06843.x

180. Kang SG, Dimitrova MN, Ortega J, Ginsburg A, Maurizi MR. Human mitochondrial ClpP is a stable heptamer that assembles into a tetradecamer in the presence of ClpX. J Biol Chem. (2005) 280:35424-32. doi: 10.1074/jbc.M507240200

181. Bender T, Lewrenz I, Franken S, Baitzel C, Voos W. Mitochondrial enzymes are protected from stress-induced aggregation by mitochondrial chaperones and the Pim1/LON protease. Mol Biol Cell. (2011) 22:54154. doi: 10.1091/mbc.e10-08-0718

182. Fischer F, Langer JD, Osiewacz HD. Identification of potential mitochondrial CLPXP protease interactors and substrates suggests its central role in energy metabolism. Sci Rep. (2015) 5:18375. doi: 10.1038/srep18375

183. Ohba Y, MacVicar T, Langer T. Regulation of mitochondrial plasticity by the i-AAA protease YME1L. Biol Chem. (2020) 401:877-90. doi: 10.1515/hsz-2020-0120

184. Baker MJ, Mooga VP, Guiard B, Langer T, Ryan MT, Stojanovski D. Impaired folding of the mitochondrial small TIM chaperones induces clearance by the i-AAA protease. J Mol Biol. (2012) 424:227-39. doi: 10.1016/j.jmb.2012.09.019

185. Wu X, Li L, Jiang H. Mitochondrial inner-membrane protease Ymel degrades outer-membrane proteins Tom22 and Om45. J Cell Biol. (2018) 217:139-49. doi: 10.1083/jcb.201702125

186. Deshwal S, Fiedler KU, Langer T. Mitochondrial proteases: multifaceted regulators of mitochondrial plasticity. Annu Rev Biochem. (2020) 89:50128. doi: 10.1146/annurev-biochem-062917-012739

187. Opalinska M, Janska H. AAA proteases: guardians of mitochondrial function and homeostasis. Cells. (2018) 7:100163. doi: 10.3390/cells7100163

188. Hoppins S, Collins SR, Cassidy-Stone A, Hummel E, Devay RM, Lackner LL, et al. A mitochondrial-focused genetic interaction map reveals a scaffold-like complex required for inner membrane organization in mitochondria. J Cell Biol. (2011) 195:323-40. doi: 10.1083/jcb.201107053

189. Harner M, Korner C, Walther D, Mokranjac D, Kaesmacher J, Welsch U, et al. The mitochondrial contact site complex, a determinant of mitochondrial architecture. EMBO J. (2011) 30:4356-70. doi: 10.1038/emboj.2011.379

190. Pfanner N, van der Laan M, Amati P, Capaldi RA, Caudy AA, Chacinska A, et al. Uniform nomenclature for the mitochondrial contact site and cristae organizing system. J Cell Biol. (2014) 204:1083-6. doi: 10.1083/jcb.201401006

191. Bohnert M, Wenz LS, Zerbes RM, Horvath SE, Stroud DA, von der Malsburg $\mathrm{K}$, et al. Role of mitochondrial inner membrane organizing system in protein biogenesis of the mitochondrial outer membrane. Mol Biol Cell. (2012) 23:3948-56. doi: 10.1091/mbc.e12-04-0295

192. Ehses S, Raschke I, Mancuso G, Bernacchia A, Geimer S, Tondera D, et al. Regulation of OPA1 processing and mitochondrial fusion by $\mathrm{m}$ AAA protease isoenzymes and OMA1. J Cell Biol. (2009) 187:102336. doi: $10.1083 /$ jcb.200906084

193. Ishihara N, Fujita Y, Oka T, Mihara K. Regulation of mitochondrial morphology through proteolytic cleavage of OPA1. EMBO J. (2006) 25:296677. doi: $10.1038 /$ sj.emboj.7601184

194. Anand R, Wai T, Baker MJ, Kladt N, Schauss AC, Rugarli E, et al. The i-AAA protease YME1L and OMA1 cleave OPA1 to balance mitochondrial fusion and fission. J Cell Biol. (2014) 204:919-29. doi: 10.1083/jcb.201308006
195. Wai T, Garcia-Prieto J, Baker MJ, Merkwirth C, Benit P, Rustin P, et al. Imbalanced OPA1 processing and mitochondrial fragmentation cause heart failure in mice. Science. (2015) 350:aad0116. doi: 10.1126/science.aad0116

196. Ellenrieder L, Opalinski L, Becker L, Kruger V, Mirus O, Straub $\mathrm{SP}$, et al. Separating mitochondrial protein assembly and endoplasmic reticulum tethering by selective coupling of Mdm10. Nat Commun. (2016) 7:13021. doi: 10.1038/ncomms13021

197. Stroud DA, Oeljeklaus S, Wiese S, Bohnert M, Lewandrowski U, Sickmann A, et al. Composition and topology of the endoplasmic reticulum-mitochondria encounter structure. J Mol Biol. (2011) 413:74350. doi: 10.1016/j.jmb.2011.09.012

198. Muller CS, Bildl W, Haupt A, Ellenrieder L, Becker T, Hunte C, et al. Cryoslicing blue native-mass spectrometry (csBN-MS), a novel technology for high resolution complexome profiling. Mol Cell Proteomics. (2016) 15:66981. doi: $10.1074 /$ mcp.M115.054080

199. Elbaz-Alon Y, Eisenberg-Bord M, Shinder V, Stiller SB, Shimoni E, Wiedemann $\mathrm{N}$, et al. Lam6 regulates the extent of contacts between organelles. Cell Rep. (2015) 12:7-14. doi: 10.1016/j.celrep.2015.06.022

200. Murley A, Sarsam RD, Toulmay A, Yamada J, Prinz WA, Nunnari J. Ltcl is an ER-localized sterol transporter and a component of ERmitochondria and ER-vacuole contacts. J Cell Biol. (2015) 209:53948. doi: $10.1083 /$ jcb. 201502033

201. Meisinger C, Wiedemann N, Rissler M, Strub A, Milenkovic D, Schonfisch B, et al. Mitochondrial protein sorting: differentiation of beta-barrel assembly by Tom7-mediated segregation of Mdm10. J Biol Chem. (2006) 281:2281926. doi: 10.1074/jbc.M602679200

202. Kornmann B, Currie E, Collins SR, Schuldiner M, Nunnari J, Weissman JS, et al. An ER-mitochondria tethering complex revealed by a synthetic biology screen. Science. (2009) 325:477-81. doi: 10.1126/science.1175088

203. Meisinger C, Rissler M, Chacinska A, Szklarz LK, Milenkovic D, Kozjak V, et al. The mitochondrial morphology protein Mdm10 functions in assembly of the preprotein translocase of the outer membrane. Dev Cell. (2004) 7:61-71. doi: 10.1016/j.devcel.2004.06.003

204. Yamano K, Tanaka-Yamano S, Endo T. Mdm10 as a dynamic constituent of the TOB/SAM complex directs coordinated assembly of Tom40. EMBO Rep. (2010) 11:187-93. doi: 10.1038/embor.2009.283

205. Flinner N, Ellenrieder L, Stiller SB, Becker T, Schleiff E, Mirus O. Mdm10 is an ancient eukaryotic porin co-occurring with the ERMES complex. Biochim Biophys Acta. (2013) 1833:3314-25. doi: 10.1016/j.bbamcr.2013.10.006

206. Boengler K, Gres P, Cabestrero A, Ruiz-Meana M, Garcia-Dorado D, Heusch $\mathrm{G}$, et al. Prevention of the ischemia-induced decrease in mitochondrial Tom20 content by ischemic preconditioning. J Mol Cell Cardiol. (2006) 41:426-30. doi: 10.1016/j.yjmcc.2006.05.015

207. Feng R, Cai M, Wang X, Zhang J, Tian Z. Early aerobic exercise combined with hydrogen-rich saline as preconditioning protects myocardial injury induced by acute myocardial infarction in rats. Appl Biochem Biotechnol. (2019) 187:663-76. doi: 10.1007/s12010-018-2841-0

208. Budas GR, Churchill EN, Disatnik MH, Sun L, Mochly-Rosen D. Mitochondrial import of PKCepsilon is mediated by HSP90: a role in cardioprotection from ischaemia and reperfusion injury. Cardiovasc Res. (2010) 88:83-92. doi: $10.1093 /$ cvr/cvq154

209. Srisakuldee W, Makazan Z, Nickel BE, Zhang F, Thliveris JA, Pasumarthi $\mathrm{KB}$, et al. The FGF-2-triggered protection of cardiac subsarcolemmal mitochondria from calcium overload is mitochondrial connexin 43dependent. Cardiovasc Res. (2014) 103:72-80. doi: 10.1093/cvr/cvu066

210. Paillard M, Tubbs E, Thiebaut PA, Gomez L, Fauconnier J, Da Silva CC, et al. Depressing mitochondria-reticulum interactions protects cardiomyocytes from lethal hypoxia-reoxygenation injury. Circulation. (2013) 128:155565. doi: 10.1161/CIRCULATIONAHA.113.001225

211. Zhang J, Li M, Zhang Z, Zhu R, Olcese R, Stefani E, et al. The mitochondrial BKCa channel cardiac interactome reveals BKCa association with the mitochondrial import receptor subunit Tom22, and the adenine nucleotide translocator. Mitochondrion. (2017) 33:84-101. doi: 10.1016/j.mito.2016.08.017

212. Bose HS, Whittal RM, Marshall B, Rajapaksha M, Wang NP, Bose M, et al. A novel mitochondrial complex of aldosterone synthase, steroidogenic acute regulatory protein, and Tom 22 synthesizes aldosterone in the rat heart. $J$ Pharmacol Exp Ther. (2021) 377:108-20. doi: 10.1124/jpet.120.000365 
213. Benak D, Sotakova-Kasparova D, Neckar J, Kolar F, Hlavackova M. Selection of optimal reference genes for gene expression studies in chronically hypoxic rat heart. Mol Cell Biochem. (2019) 461:15-22. doi: 10.1007/s11010-019-03584-x

214. Middelberg RP, Ferreira MA, Henders AK, Heath AC, Madden PA, Montgomery GW, et al. Genetic variants in LPL, OASL and TOMM40/APOE-C1-C2-C4 genes are associated with multiple cardiovascular-related traits. BMC Med Genet. (2011) 12:123. doi: 10.1186/1471-2350-12-123

215. Jeemon P, Pettigrew K, Sainsbury C, Prabhakaran D, Padmanabhan S. Implications of discoveries from genome-wide association studies in current cardiovascular practice. World J Cardiol. (2011) 3:23047. doi: 10.4330/wjc.v3.i7.230

216. Yang Z, Sun W, Hu K. Molecular mechanism underlying adenosine receptormediated mitochondrial targeting of protein kinase C. Biochim Biophys Acta. (2012) 1823:950-8. doi: 10.1016/j.bbamcr.2011.12.012

217. Kang C, Qin J, Osei W, Hu K. Regulation of protein kinase C-epsilon and its age-dependence. Biochem Biophys Res Commun. (2017) 482:120106. doi: 10.1016/j.bbrc.2016.12.012

218. Li J, Qi M, Li C, Shi D, Zhang D, Xie D, et al. Tom70 serves as a molecular switch to determine pathological cardiac hypertrophy. Cell Res. (2014) 24:977-93. doi: 10.1038/cr.2014.94

219. Pei HF, Hou JN, Wei FP, Xue Q, Zhang F, Peng CF, et al. Melatonin attenuates postmyocardial infarction injury via increasing Tom70 expression. J Pineal Res. (2017) 62:12371. doi: 10.1111/jpi.12371

220. Lochner A, Marais E, Huisamen B. Melatonin and cardioprotection against ischaemia/reperfusion injury: what's new? A review. J Pineal Res. (2018) 65:e12490. doi: 10.1111/jpi.12490

221. Kato H, Lu Q, Rapaport D, Kozjak-Pavlovic V. Tom70 is essential for PINK1 import into mitochondria. PLoS ONE. (2013) 8:e58435. doi: 10.1371/journal.pone.0058435

222. Xue Q, Pei H, Liu Q, Zhao M, Sun J, Gao E, et al. MICU1 protects against myocardial ischemia/reperfusion injury and its control by the importer receptor Tom70. Cell Death Dis. (2017) 8:e2923. doi: 10.1038/cddis.20 17.280

223. Garg V, Hu K. Protein kinase C isoform-dependent modulation of ATP-sensitive $\mathrm{K}+$ channels in mitochondrial inner membrane. Am J Physiol Heart Circ Physiol. (2007) 293:H322-32. doi: 10.1152/ajpheart.0103 5.2006

224. Mayr M, Liem D, Zhang J, Li X, Avliyakulov NK, Yang JI, et al. Proteomic and metabolomic analysis of cardioprotection: Interplay between protein kinase $\mathrm{C}$ epsilon and delta in regulating glucose metabolism of murine hearts. $\mathrm{J} \mathrm{Mol}$ Cell Cardiol. (2009) 46:268-77. doi: 10.1016/j.yjmcc.2008.10.008

225. Yuan Y, Pan SS. Parkin mediates mitophagy to participate in cardioprotection induced by late exercise preconditioning but Bnip3 does not. J Cardiovasc Pharmacol. (2018) 71:30316. doi: 10.1097/FJC.0000000000000572

226. Wang $\mathrm{P}$, Wang D, Yang $\mathrm{Y}$, Hou J, Wan J, Ran F, et al. Tom70 protects against diabetic cardiomyopathy through its antioxidant and antiapoptotic properties. Hypertens Res. (2020) 43:1047-56. doi: 10.1038/s41440-020-0518-x

227. Botta A, Laher I, Beam J, Decoffe D, Brown K, Halder S, et al. Short term exercise induces PGC-1alpha, ameliorates inflammation and increases mitochondrial membrane proteins but fails to increase respiratory enzymes in aging diabetic hearts. PLoS ONE. (2013) 8:e70248. doi: 10.1371/journal.pone.0070248

228. Giorgianni F, Usman Khan M, Weber KT, Gerling IC, BeranovaGiorgianni S. Phosphoproteome mapping of cardiomyocyte mitochondria in a rat model of heart failure. Mol Cell Biochem. (2014) 389:15967. doi: 10.1007/s11010-013-1937-7

229. Palmer ND, Kahali B, Kuppa A, Chen Y, Du X, Feitosa MF, et al. Allele specific variation at APOE increases non-alcoholic fatty liver disease and obesity but decreases risk of Alzheimer's disease and myocardial infarction. Hum Mol Genet. (2021) 2021:ddab096. doi: 10.1093/hmg/ddab096

230. Talmud PJ, Drenos F, Shah S, Shah T, Palmen J, Verzilli C, et al. Gene-centric association signals for lipids and apolipoproteins identified via the HumanCVD BeadChip. Am J Hum Genet. (2009) 85:62842. doi: 10.1016/j.ajhg.2009.10.014
231. Kong X, Zhao Q, Xing X, Zhang B, Zhang X, Hong J, et al. Genetic variants associated with lipid profiles in Chinese patients with type 2 diabetes. PLoS ONE. (2015) 10:e0135145. doi: 10.1371/journal.pone.0135145

232. Abe S, Tokoro F, Matsuoka R, Arai M, Noda T, Watanabe S, et al. Association of genetic variants with dyslipidemia. Mol Med Rep. (2015) 12:5429-36. doi: 10.3892/mmr.2015.4081

233. Park S, Kang S. A minor allele of the haplotype located in the 19q13 loci is associated with a decreased risk of hyper-LDL-cholesterolemia, and a balanced diet and high protein intake can reduce the risk. Lipids Health Dis. (2020) 19:178. doi: 10.1186/s12944-020-01352-1

234. Christiansen MK, Larsen SB, Nyegaard M, Neergaard-Petersen $S$, Ajjan R, Wurtz $M$, et al. Coronary artery disease-associated genetic variants and biomarkers of inflammation. PLoS ONE. (2017) 12:e0180365. doi: 10.1371/journal.pone.0180365

235. Kraja AT, Chasman DI, North KE, Reiner AP, Yanek LR, Kilpelainen TO, et al. Pleiotropic genes for metabolic syndrome and inflammation. Mol Genet Metab. (2014) 112:317-38. doi: 10.1016/j.ymgme.2014.04.007

236. Zeh R. Neurological and Molecular Biological Characterisation of the Mutant Mouse Line Tom40. Munich: Technische Universität München. (2013).

237. Wang X, Wang S, Liu W, Wang T, Wang J, Gao X, et al. Epigenetic upregulation of miR-126 induced by heat stress contributes to apoptosis of rat cardiomyocytes by promoting Tomm40 transcription. J Mol Cell Cardiol. (2019) 129:39-48. doi: 10.1016/j.yjmcc.2018.10.005

238. Barcena ML, Pozdniakova S, Haritonow N, Breiter P, Kuhl AA, Milting $\mathrm{H}$, et al. Dilated cardiomyopathy impairs mitochondrial biogenesis and promotes inflammation in an age- and sex-dependent manner. Aging. (2020) 12:24117-33. doi: 10.18632/aging.202283

239. Yeo A, Li L, Warren L, Aponte J, Fraser D, King K, et al. Pharmacogenetic meta-analysis of baseline risk factors, pharmacodynamic, efficacy and tolerability endpoints from two large global cardiovascular outcomes trials for darapladib. PLoS ONE. (2017) 12:e0182115. doi: 10.1371/journal.pone.0182115

240. Guo Y, Cheong N, Zhang Z, De Rose R, Deng Y, Farber SA, et al. Tim50, a component of the mitochondrial translocator, regulates mitochondrial integrity and cell death. J Biol Chem. (2004) 279:2481325. doi: 10.1074/jbc.M402049200

241. Tang K, Zhao Y, Li H, Zhu M, Li W, Liu W, et al. Translocase of inner membrane 50 functions as a novel protective regulator of pathological cardiac hypertrophy. J Am Heart Assoc. (2017) 6:4346. doi: 10.1161/JAHA.116.004346

242. Zhang XX, Wu XS, Mi SH, Fang SJ, Liu S, Xin Y, et al. Neuregulin-1 promotes mitochondrial biogenesis, attenuates mitochondrial dysfunction, and prevents hypoxia/reoxygenation injury in neonatal cardiomyocytes. Cell Biochem Funct. (2020) 38:549-57. doi: 10.1002/cbf.3503

243. Schubert C, Raparelli V, Westphal C, Dworatzek E, Petrov G, Kararigas G, et al. Reduction of apoptosis and preservation of mitochondrial integrity under ischemia/reperfusion injury is mediated by estrogen receptor beta. Biol Sex Differ. (2016) 7:53. doi: 10.1186/s13293-016-0104-8

244. Bian X, Teng T, Zhao H, Qin J, Qiao Z, Sun Y, et al. Zinc prevents mitochondrial superoxide generation by inducing mitophagy in the setting of hypoxia/reoxygenation in cardiac cells. Free Radic Res. (2018) 52:8091. doi: 10.1080/10715762.2017.1414949

245. Williamson CL, Dabkowski ER, Dillmann WH, Hollander JM. Mitochondria protection from hypoxia/reoxygenation injury with mitochondria heat shock protein 70 overexpression. Am J Physiol Heart Circ Physiol. (2008) 294:H249-56. doi: 10.1152/ajpheart.00775.2007

246. Zhou TT, Wang XY, Huang J, Deng YZ, Qiu LJ, Liu HY, et al. Mitochondrial translocation of DJ-1 is mediated by Grp75: implication in cardioprotection of resveratrol against hypoxia/reoxygenationinduced oxidative stress. J Cardiovasc Pharmacol. (2020) 75:305-13. doi: 10.1097/FJC.0000000000000805

247. Baseler WA, Dabkowski ER, Williamson CL, Croston TL, Thapa $\mathrm{D}$, Powell MJ, et al. Proteomic alterations of distinct mitochondrial subpopulations in the type 1 diabetic heart: contribution of protein import dysfunction. Am J Physiol Regul Integr Comp Physiol. (2011) 300:R186200. doi: 10.1152/ajpregu.00423.2010

248. Shepherd DL, Hathaway QA, Nichols CE, Durr AJ, Pinti MV, Hughes $\mathrm{KM}$, et al. Mitochondrial proteome disruption in the diabetic heart 
through targeted epigenetic regulation at the mitochondrial heat shock protein 70 (mtHsp70) nuclear locus. J Mol Cell Cardiol. (2018) 119:10415. doi: 10.1016/j.yjmcc.2018.04.016

249. Kirmanoglou K, Hannekum A, Schafler AE. Expression of mortalin in patients with chronic atrial fibrillation. Basic Res Cardiol. (2004) 99:4048. doi: 10.1007/s00395-004-0477-4

250. Davey KM, Parboosingh JS, McLeod DR, Chan A, Casey R, Ferreira P, et al. Mutation of DNAJC19, a human homologue of yeast inner mitochondrial membrane co-chaperones, causes DCMA syndrome, a novel autosomal recessive Barth syndrome-like condition. J Med Genet. (2006) 43:38593. doi: $10.1136 /$ jmg.2005.036657

251. Ojala T, Polinati P, Manninen T, Hiippala A, Rajantie J, Karikoski $\mathrm{R}$, et al. New mutation of mitochondrial DNAJC19 causing dilated and noncompaction cardiomyopathy, anemia, ataxia, and male genital anomalies. Pediatr Res. (2012) 72:432-7. doi: 10.1038/pr.2012.92

252. Ucar SK, Mayr JA, Feichtinger RG, Canda E, Coker M, Wortmann SB. Previously unreported biallelic mutation in DNAJC19: are sensorineural hearing loss and basal ganglia lesions additional features of dilated cardiomyopathy and ataxia (DCMA) syndrome? JIMD Rep. (2017) 35:3945. doi: 10.1007/8904_2016_23

253. Al Teneiji A, Siriwardena K, George K, Mital S, Mercimek-Mahmutoglu S. Progressive cerebellar atrophy and a novel homozygous pathogenic DNAJC19 variant as a cause of dilated cardiomyopathy ataxia syndrome. Pediatr Neurol. (2016) 62:58-61. doi: 10.1016/j.pediatrneurol.2016.03.020

254. Sparkes R, Patton D, Bernier F. Cardiac features of a novel autosomal recessive dilated cardiomyopathic syndrome due to defective importation of mitochondrial protein. Cardiol Young. (2007) 17:215-7. doi: 10.1017/S1047951107000042

255. Vasilescu C, Ojala TH, Brilhante V, Ojanen S, Hinterding HM, Palin E, et al. Genetic basis of severe childhood-onset cardiomyopathies. J Am Coll Cardiol. (2018) 72:2324-38. doi: 10.1016/j.jacc.2018.08.2171

256. Mehawej C, Delahodde A, Legeai-Mallet L, Delague V, Kaci N, Desvignes JP, et al. The impairment of MAGMAS function in human is responsible for a severe skeletal dysplasia. PLoS Genet. (2014) 10:e1004311. doi: 10.1371/journal.pgen.1004311

257. Rodriguez-Sinovas A, Boengler K, Cabestrero A, Gres P, Morente M, RuizMeana M, et al. Translocation of connexin 43 to the inner mitochondrial membrane of cardiomyocytes through the heat shock protein 90-dependent TOM pathway and its importance for cardioprotection. Circ Res. (2006) 99:93-101. doi: 10.1161/01.RES.0000230315.56904.de

258. Nguyen T, Wong R, Wang G, Gucek M, Steenbergen C, Murphy E. Acute inhibition of GSK causes mitochondrial remodeling. Am J Physiol Heart Circ Physiol. (2012) 302:H2439-45. doi: 10.1152/ajpheart.00033.2012

259. Small BA, Lu Y, Hsu AK, Gross GJ, Gross ER. Morphine reduces myocardial infarct size via heat shock protein 90 in rodents. Biomed Res Int. (2015) 2015:129612. doi: 10.1155/2015/129612

260. Tu RH Li QJ, Huang Z, He Y, Meng JJ, Zheng HL, Zeng ZY, et al. Novel functional role of heat shock protein 90 in mitochondrial connexin 43mediated hypoxic postconditioning. Cell Physiol Biochem. (2017) 44:98297. doi: 10.1159/000485399

261. Barksdale KA, Bijur GN. The basal flux of Akt in the mitochondria is mediated by heat shock protein 90 . J Neurochem. (2009) 108:128999. doi: 10.1111/j.1471-4159.2009.05878.x

262. Borillo GA, Mason M, Quijada P, Volkers M, Cottage C, McGregor M, et al. Pim-1 kinase protects mitochondrial integrity in cardiomyocytes. Circ Res. (2010) 106:1265-74. doi: 10.1161/CIRCRESAHA.109.212035

263. Fan F, Duan Y, Yang F, Trexler C, Wang H, Huang L, et al. Deletion of heat shock protein 60 in adult mouse cardiomyocytes perturbs mitochondrial protein homeostasis and causes heart failure. Cell Death Differ. (2020) 27:587-600. doi: 10.1038/s41418-019-0374-x

264. Lin KM, Hollander JM, Kao VY, Lin B, Macpherson L, Dillmann WH. Myocyte protection by $10 \mathrm{kD}$ heat shock protein (Hsp10) involves the mobile loop and attenuation of the Ras GTP-ase pathway. FASEB J. (2004) 18:1004-6. doi: 10.1096/fj.03-0348fje

265. Schafler AE, Kirmanoglou K, Pecher P, Hannekum A, Schumacher B. Overexpression of heat shock protein 60/10 in myocardium of patients with chronic atrial fibrillation. Ann Thorac Surg. (2002) 74:76770. doi: 10.1016/S0003-4975(02)03830-4
266. Agsteribbe E, Huckriede A, Veenhuis M, Ruiters MH, Niezen-Koning $\mathrm{KE}$, Skjeldal $\mathrm{OH}$, et al. A fatal, systemic mitochondrial disease with decreased mitochondrial enzyme activities, abnormal ultrastructure of the mitochondria and deficiency of heat shock protein 60. Biochem Biophys Res Commun. (1993) 193:146-54. doi: 10.1006/bbrc.1993.1602

267. Joshi M, Anselm I, Shi J, Bale TA, Towne M, Schmitz-Abe K, et al. Mutations in the substrate binding glycine-rich loop of the mitochondrial processing peptidase-alpha protein (PMPCA) cause a severe mitochondrial disease. Cold Spring Harb Mol Case Stud. (2016) 2:a000786. doi: 10.1101/mcs.a000786

268. Eldomery MK, Akdemir ZC, Vogtle FN, Charng WL, Mulica P, Rosenfeld JA, et al. MIPEP recessive variants cause a syndrome of left ventricular non-compaction, hypotonia, and infantile death. Genome Med. (2016) 8:106. doi: 10.1186/s13073-016-0360-6

269. Crewe C, Schafer C, Lee I, Kinter M, Szweda LI. Regulation of pyruvate dehydrogenase kinase 4 in the heart through degradation by the lon protease in response to mitochondrial substrate availability. J Biol Chem. (2017) 292:305-12. doi: 10.1074/jbc.M116.754127

270. Hoshino A, Okawa Y, Ariyoshi M, Kaimoto S, Uchihashi M, Fukai $\mathrm{K}$, et al. Oxidative post-translational modifications develop LONP1 dysfunction in pressure overload heart failure. Circ Heart Fail. (2014) 7:5009. doi: 10.1161/CIRCHEARTFAILURE.113.001062

271. Zhan R, Guo W, Gao X, Liu X, Xu K, Tang B. Real-time in situ monitoring of Lon and Caspase- 3 for assessing the state of cardiomyocytes under hypoxic conditions via a novel Au-Se fluorescent nanoprobe. Biosens Bioelectron. (2021) 176:112965. doi: 10.1016/j.bios.2021.112965

272. Kuo CY, Chiu YC, Lee AY, Hwang TL. Mitochondrial Lon protease controls ROS-dependent apoptosis in cardiomyocyte under hypoxia. Mitochondrion. (2015) 23:7-16. doi: 10.1016/j.mito.2015.04.004

273. Sepuri NBV, Angireddy R, Srinivasan S, Guha M, Spear J, Lu B, et al. Mitochondrial LON protease-dependent degradation of cytochrome c oxidase subunits under hypoxia and myocardial ischemia. Biochim Biophys Acta Bioenerg. (2017) 1858:519-28. doi: 10.1016/j.bbabio.201 7.04.003

274. Pomatto LCD, Cline M, Woodward N, Pakbin P, Sioutas C, Morgan TE, et al. Aging attenuates redox adaptive homeostasis and proteostasis in female mice exposed to traffic-derived nanoparticles ("vehicular smog"). Free Radic Biol Med. (2018) 121:86-97. doi: 10.1016/j.freeradbiomed.2018.04.574

275. Delaval E, Perichon M, Friguet B. Age-related impairment of mitochondrial matrix aconitase and ATP-stimulated protease in rat liver and heart. Eur $J$ Biochem. (2004) 271:4559-64. doi: 10.1111/j.1432-1033.2004.04422.x

276. Guillon B, Bulteau AL, Wattenhofer-Donze M, Schmucker S, Friguet B, Puccio $\mathrm{H}$, et al. Frataxin deficiency causes upregulation of mitochondrial Lon and ClpP proteases and severe loss of mitochondrial Fe-S proteins. FEBS J. (2009) 276:1036-47. doi: 10.1111/j.1742-4658.2008.06847.x

277. Wu B, Li J, Ni H, Zhuang X, Qi Z, Chen Q, et al. TLR4 activation promotes the progression of experimental autoimmune myocarditis to dilated cardiomyopathy by inducing mitochondrial dynamic imbalance. Oxid Med Cell Longev. (2018) 2018:3181278. doi: 10.1155/2018/3181278

278. Hu Y, Xu Y, Chen W, Qiu Z. Stomatin-like protein-2: a potential target to treat mitochondrial cardiomyopathy. Heart Lung Circ. (2021) 5:74. doi: 10.1016/j.hlc.2021.05.074

279. Zhao Y, Zhu J, Zhang N, Liu Q, Wang Y, Hu X, et al. GDF11 enhances therapeutic efficacy of mesenchymal stem cells for myocardial infarction via YME1L-mediated OPA1 processing. Stem Cells Transl Med. (2020) 9:125771. doi: $10.1002 / \mathrm{sctm} .20-0005$

280. Seiferling D, Szczepanowska K, Becker C, Senft K, Hermans S, Maiti $\mathrm{P}$, et al. Loss of CLPP alleviates mitochondrial cardiomyopathy without affecting the mammalian UPRmt. EMBO Rep. (2016) 17:953-64. doi: 10.15252/embr.201642077

281. Mayr JA, Haack TB, Graf E, Zimmermann FA, Wieland T, Haberberger B, et al. Lack of the mitochondrial protein acylglycerol kinase causes Sengers syndrome. Am J Hum Genet. (2012) 90:314-20. doi: 10.1016/j.ajhg.2011.12.005

282. Allali S, Dorboz I, Samaan S, Slama A, Rambaud C, BoespflugTanguy $\mathrm{O}$, et al. Mutation in the AGK gene in two siblings with unusual Sengers syndrome. Metab Brain Dis. (2017) 32:2149-54. doi: 10.1007/s11011-017-0101-6 
283. Khatter S, Puri RD, Bijarnia-Mahay S, Aggarwal M, Ramprasad V, Saxena $\mathrm{R}$, et al. Sengers syndrome in Asian Indians-two novel mutations and variant phenotype-genotype correlation. Transl Sci Rare Dis. (2017) 2:15764. doi: 10.3233/TRD-170017

284. Haghighi A, Haack TB, Atiq M, Mottaghi H, Haghighi-Kakhki H, Bashir RA, et al. Sengers syndrome: six novel AGK mutations in seven new families and review of the phenotypic and mutational spectrum of 29 patients. Orphanet J Rare Dis. (2014) 9:119. doi: 10.1186/s13023-014-0119-3

285. Kang Y, Stroud DA, Baker MJ, De Souza DP, Frazier AE, Liem M, et al. Sengers syndrome-associated mitochondrial acylglycerol kinase is a subunit of the human TIM22 protein import complex. Mol Cell. (2017) 67:457-70 e5. doi: 10.1016/j.molcel.2017.06.014

286. Kor D, Yilmaz B, Horoz O, Ceylaner G, Sizmaz S, Demir F. Two novel mutations in the AGK gene: two case reports with Sengers syndrome. Gene Technol. (2016) 5:2. doi: 10.4172/2329-6682.1000140

287. Dabir DV, Hasson SA, Setoguchi K, Johnson ME, Wongkongkathep $\mathrm{P}$, Douglas CJ, et al. A small molecule inhibitor of redoxregulated protein translocation into mitochondria. Dev Cell. (2013) 25:81-92. doi: 10.1016/j.devcel.2013.03.006

288. Berger I, Ben-Neriah Z, Dor-Wolman T, Shaag A, Saada A, Zenvirt S, et al. Early prenatal ventriculomegaly due to an AIFM1 mutation identified by linkage analysis and whole exome sequencing. Mol Genet Metab. (2011) 104:517-20. doi: 10.1016/j.ymgme.2011.09.020

289. Heimer G, Eyal E, Zhu X, Ruzzo EK, Marek-Yagel D, Sagiv D, et al. Mutations in AIFM1 cause an X-linked childhood cerebellar ataxia partially responsive to riboflavin. Eur J Paediatr Neurol. (2018) 22:93101. doi: 10.1016/j.ejpn.2017.09.004

290. Joza N, Oudit GY, Brown D, Benit P, Kassiri Z, Vahsen N, et al. Musclespecific loss of apoptosis-inducing factor leads to mitochondrial dysfunction, skeletal muscle atrophy, and dilated cardiomyopathy. Mol Cell Biol. (2005) 25:10261-72. doi: 10.1128/MCB.25.23.10261-10272.2005

291. van Empel VP, Bertrand AT, van der Nagel R, Kostin S, Doevendans PA, Crijns HJ, et al. Downregulation of apoptosis-inducing factor in harlequin mutant mice sensitizes the myocardium to oxidative stress-related cell death and pressure overload-induced decompensation. Circ Res. (2005) 96:e92e101. doi: 10.1161/01.RES.0000172081.30327.28

292. Xu A, Szczepanek K, Hu Y, Lesnefsky EJ, Chen Q. Cardioprotection by modulation of mitochondrial respiration during ischemia-reperfusion: role of apoptosis-inducing factor. Biochem Biophys Res Commun. (2013) 435:627-33. doi: 10.1016/j.bbrc.2013.05.033

293. Chen L, Shi D, Guo M. The roles of PKC-delta and PKC-epsilon in myocardial ischemia/reperfusion injury. Pharmacol Res. (2021) 170:105716. doi: 10.1016/j.phrs.2021.105716

294. Javadov S, Karmazyn M, Escobales N. Mitochondrial permeability transition pore opening as a promising therapeutic target in cardiac diseases. $J$ Pharmacol Exp Ther. (2009) 330:670-8. doi: 10.1124/jpet.109.153213

295. Schleiff E, Silvius JR, Shore GC. Direct membrane insertion of voltagedependent anion-selective channel protein catalyzed by mitochondrial Tom20. J Cell Biol. (1999) 145:973-8. doi: 10.1083/jcb.145.5.973

296. Shi D, Qi M, Zhou L, Li X, Ni L, Li C, et al. Endothelial mitochondrial preprotein translocase Tomm7-Rac1 signaling axis dominates cerebrovascular network homeostasis. Arterioscler Thromb Vasc Biol. (2018) 38:2665-77. doi: 10.1161/ATVBAHA.118.311538

297. Richter-Dennerlein R, Korwitz A, Haag M, Tatsuta T, Dargazanli S, Baker M, et al. DNAJC19, a mitochondrial cochaperone associated with cardiomyopathy, forms a complex with prohibitins to regulate cardiolipin remodeling. Cell Metab. (2014) 20:158-71. doi: 10.1016/j.cmet.2014.04.016

298. Sinha D, Joshi N, Chittoor B, Samji P, D'Silva P. Role of Magmas in protein transport and human mitochondria biogenesis. Hum Mol Genet. (2010) 19:1248-62. doi: 10.1093/hmg/ddq002

299. Vukotic M, Nolte H, Konig T, Saita S, Ananjew M, Kruger M, et al. Acylglycerol kinase mutated in sengers syndrome is a subunit of the TIM22 protein translocase in mitochondria. Mol Cell. (2017) 67:471-83 e7. doi: 10.1016/j.molcel.2017.06.013

300. Siriwardena K, Mackay N, Levandovskiy V, Blaser S, Raiman J, Kantor PF, et al. Mitochondrial citrate synthase crystals: novel finding in Sengers syndrome caused by acylglycerol kinase (AGK) mutations. Mol Genet Metab. (2013) 108:40-50. doi: 10.1016/j.ymgme.2012.11.282
301. Hangen E, Feraud O, Lachkar S, Mou H, Doti N, Fimia GM, et al. Interaction between AIF and CHCHD4 regulates respiratory chain biogenesis. Mol Cell. (2015) 58:1001-14. doi: 10.1016/j.molcel.2015.04.020

302. Meyer K, Buettner S, Ghezzi D, Zeviani M, Bano D, Nicotera P. Loss of apoptosis-inducing factor critically affects MIA40 function. Cell Death Dis. (2015) 6:e1814. doi: 10.1038/cddis.2015.170

303. Modjtahedi N, Kroemer G. CHCHD4 links AIF to the biogenesis of respiratory chain complex I. Mol Cell Oncol. (2016) 3:e1074332. doi: 10.1080/23723556.2015.1074332

304. Bertero E, Kutschka I, Maack C, Dudek J. Cardiolipin remodeling in Barth syndrome and other hereditary cardiomyopathies. Biochim Biophys Acta Mol Basis Dis. (2020) 1866:165803. doi: 10.1016/j.bbadis.2020.165803

305. Monteiro JP, Oliveira PJ, Jurado AS. Mitochondrial membrane lipid remodeling in pathophysiology: a new target for diet and therapeutic interventions. Prog Lipid Res. (2013) 52:51328. doi: 10.1016/j.plipres.2013.06.002

306. Paradies G, Paradies V, Ruggiero FM, Petrosillo G. Role of cardiolipin in mitochondrial function and dynamics in health and disease: molecular and pharmacological aspects. Cells. (2019) 8:70728. doi: 10.3390/cells 80 70728

307. Brandner K, Mick DU, Frazier AE, Taylor RD, Meisinger C, Rehling P. Tazl, an outer mitochondrial membrane protein, affects stability and assembly of inner membrane protein complexes: implications for Barth Syndrome. Mol Biol Cell. (2005) 16:5202-14. doi: 10.1091/mbc.e05-0 3-0256

308. Sabbah HN. Barth syndrome cardiomyopathy: targeting the mitochondria with elamipretide. Heart Fail Rev. (2021) 26:23753. doi: 10.1007/s10741-020-10031-3

309. Vreken P, Valianpour F, Nijtmans LG, Grivell LA, Plecko B, Wanders RJ, et al. Defective remodeling of cardiolipin and phosphatidylglycerol in Barth syndrome. Biochem Biophys Res Commun. (2000) 279:37882. doi: $10.1006 /$ bbrc. 2000.3952

310. Gebert N, Joshi AS, Kutik S, Becker T, McKenzie M, Guan XL, et al. Mitochondrial cardiolipin involved in outer-membrane protein biogenesis: implications for Barth syndrome. Curr Biol. (2009) 19:21339. doi: 10.1016/j.cub.2009.10.074

311. Kutik S, Rissler M, Guan XL, Guiard B, Shui G, Gebert N, et al. The translocator maintenance protein Tam41 is required for mitochondrial cardiolipin biosynthesis. J Cell Biol. (2008) 183:1213-21. doi: 10.1083/jcb.200806048

312. Tamura Y, Harada Y, Yamano K, Watanabe K, Ishikawa D, Ohshima $\mathrm{C}$, et al. Identification of Tam41 maintaining integrity of the TIM23 protein translocator complex in mitochondria. J Cell Biol. (2006) 174:6317. doi: $10.1083 /$ jcb. 200603087

313. Boengler K, Schulz R. Connexin 43 and mitochondria in cardiovascular health and disease. Adv Exp Med Biol. (2017) 982:227-46. doi: 10.1007/978-3-319-55330-6_12

314. Michela P, Velia V, Aldo P, Ada P. Role of connexin 43 in cardiovascular diseases. Eur J Pharmacol. (2015) 768:71-6. doi: 10.1016/j.ejphar.2015.10.030

315. Wang M, Smith K, Yu Q, Miller C, Singh K, Sen CK. Mitochondrial connexin 43 in sex-dependent myocardial responses and estrogen-mediated cardiac protection following acute ischemia/reperfusion injury. Basic Res Cardiol. (2019) 115:1. doi: 10.1007/s00395-019-0759-5

316. Boengler K, Konietzka I, Buechert A, Heinen Y, Garcia-Dorado D, Heusch $\mathrm{G}$, et al. Loss of ischemic preconditioning's cardioprotection in aged mouse hearts is associated with reduced gap junctional and mitochondrial levels of connexin 43. Am J Physiol Heart Circ Physiol. (2007) 292:H17649. doi: 10.1152/ajpheart.01071.2006

317. Schulz R, Boengler K, Totzeck A, Luo Y, Garcia-Dorado D, Heusch G. Connexin 43 in ischemic pre- and postconditioning. Heart Fail Rev. (2007) 12:261-6. doi: 10.1007/s10741-007-9032-3

318. Ruiz-Meana M, Rodriguez-Sinovas A, Cabestrero A, Boengler K, Heusch G, Garcia-Dorado D. Mitochondrial connexin43 as a new player in the pathophysiology of myocardial ischaemia-reperfusion injury. Cardiovasc Res. (2008) 77:325-33. doi: 10.1093/cvr/cvm062

319. Saito T, Sadoshima J. Molecular mechanisms of mitochondrial autophagy/mitophagy in the heart. Circ Res. (2015) 116:147790. doi: 10.1161/CIRCRESAHA.116.303790 
320. Mukherjee UA, Ong SB, Ong SG, Hausenloy DJ. Parkinson's disease proteins: novel mitochondrial targets for cardioprotection. Pharmacol Ther. (2015) 156:34-43. doi: 10.1016/j.pharmthera.2015.10.005

321. Friederich MW, Erdogan AJ, Coughlin CR, Elos MT, Jiang H, O’Rourke $\mathrm{CP}$, et al. Mutations in the accessory subunit NDUFB10 result in isolated complex I deficiency and illustrate the critical role of intermembrane space import for complex I holoenzyme assembly. Hum Mol Genet. (2017) 26:70216. doi: $10.1093 / \mathrm{hmg} / \mathrm{ddw} 431$

322. Chis R, Sharma P, Bousette N, Miyake T, Wilson A, Backx PH, et al. alpha-Crystallin B prevents apoptosis after $\mathrm{H} 2 \mathrm{O} 2$ exposure in mouse neonatal cardiomyocytes. Am J Physiol Heart Circ Physiol. (2012) 303:H96778. doi: 10.1152/ajpheart.00040.2012

323. Zhang Y, Li XR, Zhao L, Duan GL, Xiao L, Chen HP. DJ-1 preserving mitochondrial complex I activity plays a critical role in resveratrol-mediated cardioprotection against hypoxia/reoxygenation-induced oxidative stress. Biomed Pharmacother. (2018) 98:545-52. doi: 10.1016/j.biopha.2017.12.094

324. Deng YZ, Xiao L, Zhao L, Qiu LJ, Ma ZX, Xu XW, et al. Molecular mechanism underlying hypoxic preconditioning-promoted mitochondrial translocation of DJ-1 in hypoxia/reoxygenation H9c2 cells. Molecules. (2019) 25:10071. doi: 10.3390/molecules 25010071

325. Ding H, Xu XW, Wang H, Xiao L, Zhao L, Duan GL, et al. DJ1 plays an obligatory role in the cardioprotection of delayed hypoxic preconditioning against hypoxia/reoxygenation-induced oxidative stress through maintaining mitochondrial complex I activity. Cell Biochem Funct. (2018) 36:147-54. doi: 10.1002/cbf.3326

326. Baseler WA, Dabkowski ER, Jagannathan R, Thapa D, Nichols CE, Shepherd $\mathrm{DL}$, et al. Reversal of mitochondrial proteomic loss in Type 1 diabetic heart with overexpression of phospholipid hydroperoxide glutathione peroxidase. Am J Physiol Regul Integr Comp Physiol. (2013) 304:R55365. doi: 10.1152/ajpregu.00249.2012

327. Dabkowski ER, Baseler WA, Williamson CL, Powell M, Razunguzwa TT, Frisbee JC, et al. Mitochondrial dysfunction in the type 2 diabetic heart is associated with alterations in spatially distinct mitochondrial proteomes. Am J Physiol Heart Circ Physiol. (2010) 299:H529-40. doi: 10.1152/ajpheart.00267.2010
328. Craig EE, Hood DA. Influence of aging on protein import into cardiac mitochondria. Am J Physiol. (1997) 272:H29838. doi: 10.1152/ajpheart.1997.272.6.H2983

329. Schneider JJ, Hood DA. Effect of thyroid hormone on mtHsp70 expression, mitochondrial import and processing in cardiac muscle. J Endocrinol. (2000) 165:9-17. doi: 10.1677/joe.0.1650009

330. Marin-Garcia J. Thyroid hormone and myocardial mitochondrial biogenesis. Vascul Pharmacol. (2010) 52:120-30. doi: 10.1016/j.vph.200 9.10 .008

331. Craig EE, Chesley A, Hood DA. Thyroid hormone modifies mitochondrial phenotype by increasing protein import without altering degradation. Am J Physiol. (1998) 275:C1508-15. doi: 10.1152/ajpcell.1998.27 5.6.C1508

332. Colavecchia M, Christie LN, Kanwar YS, Hood DA. Functional consequences of thyroid hormone-induced changes in the mitochondrial protein import pathway. Am J Physiol Endocrinol Metab. (2003) 284:E2935. doi: 10.1152/ajpendo.00294.2002

Conflict of Interest: The authors declare that the research was conducted in the absence of any commercial or financial relationships that could be construed as a potential conflict of interest.

Publisher's Note: All claims expressed in this article are solely those of the authors and do not necessarily represent those of their affiliated organizations, or those of the publisher, the editors and the reviewers. Any product that may be evaluated in this article, or claim that may be made by its manufacturer, is not guaranteed or endorsed by the publisher.

Copyright (C) 2021 Zhao and Zou. This is an open-access article distributed under the terms of the Creative Commons Attribution License (CC BY). The use, distribution or reproduction in other forums is permitted, provided the original author(s) and the copyright owner(s) are credited and that the original publication in this journal is cited, in accordance with accepted academic practice. No use, distribution or reproduction is permitted which does not comply with these terms. 